\title{
The effect of the farnesyl protein transferase inhibitor SCH66336 on isoprenylation and signalling by the prostacyclin receptor
}

\author{
Sarah J. O'MEARA and B. Therese KINSELLA*1 \\ Department of Biochemistry, Conway Institute of Biomolecular and Biomedical Research, University College Dublin, Belfield, Dublin 4, Ireland
}

\begin{abstract}
Like Ras, farnesylation of the IP (prostacyclin receptor) is required for its efficient intracellular signalling, and hence the IP represents a potential target for inhibition by FTIs [FTase (farnesyl protein transferase) inhibitors]. Herein, the effect of SCH66336 on the isoprenylation and function of the human and mouse IPs overexpressed in human embryonic kidney 293 cells, and by the IP endogenously expressed in human erythroleukaemia cells, was investigated. SCH66336 yielded concentration-dependent decreases in IP-mediated cAMP generation $\left(\mathrm{IC}_{50} 0.27-0.62 \mathrm{nM}\right.$ ), $\left[\mathrm{Ca}^{2+}\right]_{\mathrm{i}}$ mobilization $\left(\mathrm{IC}_{50} 26.6-48.3 \mathrm{nM}\right)$ and IP internalization, but had no effect on signalling by the non-isoprenylated $\beta_{2}$ adrenergic receptor or $\beta$ isoform of the TP (prostanoid thromboxane $\mathrm{A}_{2}$ receptor). Additionally, SCH66336 impaired IP-mediated crossdesensitization of $\mathrm{TP} \alpha$ signalling $\left(\mathrm{IC}_{50} 56.1 \mathrm{nM}\right)$ and reduced farnesylation of the molecular chaperone protein $\mathrm{HDJ}-2\left(\mathrm{IC}_{50}\right.$ $3.1 \mathrm{nM})$. To establish whether farnesylation of the IP is inhibited
\end{abstract}

and/or whether its 'CaaX motif' might undergo alternative geranylgeranylation in the presence of SCH66336, a series of chimaeric Ha (Harvey)-Ras fusions were generated by replacing its CaaX motif (-CVLS) with that of the IP (-CSLC) or, as controls, of Ki (Kirsten)-Ras 4B (-CVIM) or Rac 1 (-CVLL). Whereas SCH66336 had no effect on Ha-Ras ${ }^{\mathrm{CVLL}}$ isoprenylation in vitro or in whole cells, it supported alternative geranylgeranylation of Ha-Ras ${ }^{\text {CVIM }}$, but completely impaired isoprenylation of both HaRas $^{\text {CVLS }}$ and Ha-Ras ${ }^{\text {CSLC }}$. These data confirm that the -CSLC motif of the IP is a direct target for inhibition by the FTI SCH66336, and in the presence of strong FTase inhibition, the IP does not undergo compensatory geranylgeranylation.

Key words: desensitization, farnesyl protein transferase inhibitor, isoprenylation, prostacyclin receptor, Ras, thromboxane $A_{2}$.

\section{INTRODUCTION}

Ras guanine-nucleotide-binding proteins act as molecular switches, transducing an array of extracellular growth and differentiation signals from cell-surface receptors to the nucleus [1]. Mutations in codon 12, 13 or 61 of one of the three ras genes, i.e. Ha (Harvey)-ras, N (neuronal)-ras or Ki (Kirsten)-ras, encode a constitutively activated protein that transforms cells to a malignant phenotype by providing uninterrupted growth signals $[2,3]$. In mammalian cells, Ras becomes biologically active following a series of post-translational modifications, which allow for its subsequent localization to the inner face of the plasma membrane [4]. The first modification is initiated by the formation of a stable thioether bond between a cysteine located in a distinct C-terminal motif ( $\mathrm{CaaX}$ ) and a hydrophobic isoprenyl (farnesyl or geranylgeranyl) group derived from their pyrophosphate intermediates of the cholesterol biosynthetic pathway [4]. Farnesylation, catalysed by FTase (farnesyl protein transferase), is directed by a C-terminal CaaX motif, where ' $\mathrm{C}$ ' is cysteine, ' $\mathrm{a}$ ' is usually an aliphatic residue, and ' $X$ ' is typically methionine, serine, glutamine, cysteine or alanine. Where ' $\mathrm{X}$ ' represents a leucine or isoleucine, the protein becomes geranylgeranylated, catalysed by GGTase 1 (geranylgeranyl protein transferase 1) [4]. Proteolytic cleavage to remove the 'aaX' residues, followed by carboxylmethylation of the farnesyl/geranylgeranyl-cysteine residue, completes the CaaX-directed series of post-translational modifications [4].
Given that oncogenic mutations of the ras gene occurs in over $30 \%$ of all known human cancers, the Ras signalling pathway represents a major therapeutic target in malignant transformation [1]. Indeed, the improved understanding of the molecular mechanisms of Ras expression, processing, activation and action on downstream effectors has promulgated the development of novel agents designed to target this critical aberrant pathway [2]. Of these, the FTIs (FTase inhibitors) have shown most potential, having reached phase III clinical trial status [5]. By inhibiting farnesylation of Ras, FTIs prevent its subsequent obligate localization to the plasma membrane, and hence impair transduction of its proliferative signals [6].

SCH66336 (Ionafarnib ${ }^{\circledR}$; Sarasar $^{\circledR}$ ) was the first FTI to undergo clinical development [5]. A non-peptidyl, non-thiol tricyclic FTI, SCH66336 has demonstrated significant biological and clinical activity in a range of malignancies and solid tumours [5,6]. Confirmation of biological efficacy has been demonstrated further with surrogate markers in various clinical trials: SCH66336 inhibited prelamin A farnesylation in buccal mucosa cells at clinically relevant doses, while an $11-50 \%$ increase in non-farnesylated molecular chaperone protein HDJ-2 was observed in surgical specimens from patients treated with 100, 200 or $300 \mathrm{mg}$ SCH66336 twice daily for 8-14 days [5].

Although SCH66336 is selective in in vitro assays, there is currently insufficient published data to confirm that FTIs do not interfere, adversely or otherwise, with farnesylation and function of other unidentified proteins. In the present study, we have

Abbreviations used: $\beta_{2} \mathrm{AR}, \beta_{2}$ adrenergic receptor; [ $\left.\mathrm{Ca}^{2+}\right]_{\mathrm{i}}$, intracellular calcium; FBS, fetal bovine serum; FPP, farnesyl pyrophosphate; FTase, farnesyl protein transferase; FTI, farnesyl protein transferase inhibitor; GGPP, geranylgeranyl pyrophosphate; fura 2/AM, fura 2 acetoxymethyl ester; GGTase, geranylgeranyl protein transferase; GPCR, G-protein-coupled receptor; HA, haemagglutinin; Ha-Ras, Harvey Ras; HEK, human embryonic kidney; HEL, human erythroleukaemia; (h/m)IP, (human/mouse) prostacyclin receptor; Ki-Ras, Kirsten Ras; LDH, lactate dehydrogenase; MVA, mevalonolactone; $\mathrm{N}$-Ras, neuronal Ras; PKA, cAMP-dependent protein kinase; PLC $\beta$, phospholipase $\mathrm{C} \beta$; TXA $\mathrm{T}_{2}$, thromboxane $\mathrm{A}_{2}$; TP, prostanoid TXA $\mathrm{A}_{2}$ receptor.

1 To whom correspondence should be addressed (email Therese.Kinsella@UCD.IE). 
examined the effect of SCH66336 on farnesylation of one such protein, the IP (prostacyclin receptor). IP mediates the action of prostacyclin [prostaglandin ( $\mathrm{PG}) \mathrm{I}_{2}$ ], a labile cyclo-oxygenasederived metabolite of arachidonic acid [7]. Prostacyclin plays a prominent role in vascular haemostasis, acting as a potent inhibitor of platelet aggregation and as a vasodilator [7]. Perturbations in prostacyclin and/or IP signalling have been implicated in the pathogenesis of a number of disorders, including ischaemic heart disease, atherosclerosis, renal failure and systemic and pregnancyinduced hypertension [7-10]. The finding that both the human (h) and mouse (m) IP are farnesylated, and that this modification is absolutely required for efficient receptor-effector coupling, raises the possibility that SCH66336 may inadvertently interfere with IP signalling, and hence IP function $[11,12]$. Thus the overall aim of the present study was to investigate the effect of SCH66336 on farnesylation and intracellular signalling by hIP and mIP expressed in mammalian cells with the view to ascertaining whether the IP is a likely therapeutic target for FTI inhibition, and to assess the potential implications thereof. In addition, we sought to examine whether the 'CAAX' motif of the IP is solely a substrate for farnesylation, or whether it undergoes alternative geranylgeranylation in the presence of SCH66336.

\section{EXPERIMENTAL}

\section{Materials}

SCH66336 was obtained from Schering Plough Inc. (Kenilworth, NJ, U.S.A). Cicaprost was obtained from Schering AG (Berlin, Germany). Iloprost, $\left[{ }^{3} \mathrm{H}\right]$ iloprost $\left(15.3 \mathrm{Ci} \cdot \mathrm{mmol}^{-1}\right),\left[{ }^{3} \mathrm{H}\right] \mathrm{CGP}$ $12177\left(41.0 \mathrm{Ci} \cdot \mathrm{mmol}^{-1}\right)$ and PVDF filters were purchased from Amersham Biosciences. $\left[{ }^{3} \mathrm{H}\right] \mathrm{MVA}\left(\left[{ }^{3} \mathrm{H}\right]\right.$ mevalonolactone; $20 \mathrm{Ci}$. $\left.\mathrm{mmol}^{-1}\right),\left[{ }^{3} \mathrm{H}\right]$ farnesylpyrophosphate $\left(20 \mathrm{Ci} \cdot \mathrm{mmol}^{-1}\right),\left[{ }^{3} \mathrm{H}\right]$ geranylgeranylpyrophosphate $\left(15-30 \mathrm{Ci} \cdot \mathrm{mmol}^{-1}\right),\left[{ }^{35} \mathrm{~S}\right]$ methionine $\left(1175 \mathrm{Ci} \cdot \mathrm{mmol}^{-1}\right)$ and $\left[{ }^{3} \mathrm{H}\right] \mathrm{cAMP}\left(15-30 \mathrm{Ci} \cdot \mathrm{mmol}^{-1}\right)$ were purchased from American Radiolabeled Chemicals Inc. Isoproterenol was purchased from Sigma. Fura 2/AM (fura 2 acetoxymethyl ester) and U46619 was purchased from Calbiochem. Rabbit reticulocyte translation system (minus methionine), T7 RNA polymerase, RNasin and all restriction endonucleases were purchased from Promega Corp. Taq DNA polymerase, the chemiluminescence Western detection kit, and rat monoclonal 3F10 anti-HA (haemagglutinin) peroxidase-conjugated antibody were purchased from Roche. Horseradish peroxidase-conjugated goat anti-mouse IgG was from Santa Cruz Biotechnology. Mouse monoclonal 101R anti-HA antibody was obtained from BabCO. Anti-HDJ2 was from Neomarkers. Secondary FITC-conjugated anti-mouse IgG serum was purchased from Jackson Immunoresearch Laboratories, Inc. Oligonucleotides were synthesized by Genosys Biotechnologies. All other reagents were A. R. or molecular biology grade, and were used without further purification.

\section{Cell culture and transfections}

Human embryonic kidney (HEK).mIP, HEK.hIP, HEK.TP $\alpha$ [where ' $\mathrm{TP} \alpha$ ' is prostanoid thromboxane $\mathrm{A}_{2}\left(\mathrm{TXA}_{2}\right)$ receptor] and HEK.TP $\beta$ cells, stably overexpressing HA-epitope-tagged forms of the wild-type mIP and hIP or the human TP $\alpha$ and $\beta$ isoforms respectively, have been described previously $[11,13]$. HEK293 cells were transiently transfected with pHM- or pCMVbased vectors using the calcium phosphate/DNA co-precipitation procedure $[11,13]$ and were harvested $48 \mathrm{~h}$ post-transfection.

To generate a mammalian cell line overexpressing the $\beta_{2} \mathrm{AR}$ ( $\beta_{2}$ adrenergic receptor), a HindIII-EcoRI subfragment encod- ing the full-length cDNA for the human $\beta_{2} \mathrm{AR}$ was subcloned from the plasmid pTF3 (A.T.C.C.) into a HindIII-EcoRI site of pHM6 (Roche) to generate $\mathrm{pHM}: \beta_{2} \mathrm{AR}$. Thereafter, HEK. $\beta_{2} \mathrm{AR}$ cell lines stably overexpressing the $\beta_{2}$ AR receptor in HEK-293 cells were established, using $\mathrm{pHM}: \beta_{2} \mathrm{AR}$, and characterized essentially as described previously $[11,13]$.

\section{Subcloning and site-directed mutagenesis of the 'CaaX motif' of Ras}

The plasmid pHM:Ras was constructed by subcloning the fulllength coding sequence for wild-type human Ha-Ras (Ha-Ras ${ }^{\mathrm{WT}}$ ) from pCMV5:Ras [14] into the HindIII site of pHM6 (Roche). To generate Ha-Ras ${ }^{\mathrm{CSLC}}$, the C-terminal CaaX motif of that of

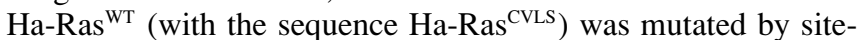
directed mutagenesis to that of the IP (with the sequence IP ${ }^{\mathrm{CSLC}}$ ). Specifically, site-directed mutagenesis of $\mathrm{Val}^{187}$ and $\mathrm{Ser}^{189}$ of Ha$\operatorname{Ras}^{\text {WT }}$ to $\operatorname{Ser}^{187}$ and Cys ${ }^{189}$ respectively to generate Ha-Ras ${ }^{\text {CSLC }}$ was performed using the following mutator oligonucleotide: $5^{\prime}$-dCTC AAG CT TCA GCA GAG C $\boldsymbol{G A}$ ACA CTT GCA GCT CAT GC-3' (antisense primer; the sequence complementary to the mutator bases are highlighted in boldface italics). Similarly, to generate $\mathrm{Ha}-\mathrm{Ras}^{\mathrm{SSLC}}, \mathrm{Cys}^{186}$, Val $^{187}$ and $\mathrm{Ser}^{189}$ of Ha-Ras ${ }^{\mathrm{WT}}$ were converted into $\mathrm{Ser}^{186}, \mathrm{Ser}^{187}$ and Cys ${ }^{189}$ respectively using the mutator oligonucleotide 5'dCTC AAG CT TCA GCA GAG CGA AGA CTT GCA GCT CAT GCA GC-3' (antisense primer; the sequence complementary to the mutator bases are highlighted in boldface italic). To generate Ha-Ras ${ }^{\text {CVLL }}, \mathrm{Ser}^{189}$ of Ha-Ras ${ }^{\text {WT }}$ was converted into Leu $^{189}$ using the mutator oligonucleotide $5^{\prime}$-dCTC AAG CT TCA GAG GAG CAC ACA CTT GCA GC-3' (antisense primer). Finally, to generate Ha-Ras ${ }^{\text {CVIM }}$, $\mathrm{Leu}^{188}$ and $\mathrm{Ser}^{189}$ of HaRas $^{\text {WT }}$ were converted into $\mathrm{Ile}^{188}$ and $\mathrm{Met}^{189}$ respectively, using the mutator oligonucleotide 5'-dAGA GGT ACC TTA $\boldsymbol{C A T} \boldsymbol{A A T}$ CAC ACA CTT GCA GCT-3' (antisense primer).

In each case, PCR mutagenesis was performed using the oligonucleotide 5'-dGAG AAG CTT G ATG ACG GAA TAT AAG CTG GTG-3' as sense primer (whereby the sequence corresponding to the initiation codon is underlined) in combination with the specified mutator oligonucleotide, as antisense primer, using the plasmid pCMV:Ras [14] as a template. Thereafter, PCR-generated products were subcloned in-frame into the HindIII site of pHM6 to generate the plasmids pHM:Ras ${ }^{\mathrm{CSLC}}$, $\mathrm{pHM}: \mathrm{Ras}^{\mathrm{SSLC}}$, pHM:Ras ${ }^{\mathrm{CVLL}}$ or, in the case of $\mathrm{Ras}^{\mathrm{CVIM}}$, into HindIII-KpNI sites of pHM6 to generate the plasmid pHM:Ras ${ }^{\mathrm{CVIM}}$. All resulting plasmids were verified by double-stranded DNA sequence analysis and encode HA-epitope-tagged forms of Ha-Ras ${ }^{\text {WT }}$, Ha$\mathrm{Ras}^{\mathrm{CSLC}}$, Ha-Ras ${ }^{\mathrm{SSLC}}$, Ha-Ras ${ }^{\mathrm{CVLL}}$ and Ha-Ras ${ }^{\mathrm{CVIM}}$ respectively.

\section{Radioligand binding studies}

$\left[{ }^{3} \mathrm{H}\right]$ Iloprost radioligand binding assays of the IP were performed on cell membranes, as described previously [11]. $\beta_{2} \mathrm{AR}$ and TP radioligand assays were performed on whole cells, as described previously $[13,15]$. Where specified, cells were pre-incubated with either $1 \mu \mathrm{M}$ SCH66336 (added from 1000-fold-concentrated stocks diluted in $0.0001 \%$ DMSO) or with the corresponding volume of vehicle (DMSO) for $16 \mathrm{~h}$ before harvesting.

\section{Measurement of SCH66336-induced cytotoxicity}

Possible cytotoxic effects of SCH66336 were evaluated by measuring LDH (lactate dehydrogenase) release following exposure of cells for $24 \mathrm{~h}$ with $1 \mathrm{nM}, 20 \mathrm{nM}$ and $1000 \mathrm{nM}$ SCH66336 using a Cytotox 96 Non-Radioactive Cytotoxicity assay kit (Promega), essentially as described by the manufacturer. 
The percentage of LDH released from the cells was determined by expressing the level of SCH66336-induced LDH released as a fractional percentage of the maximum $\mathrm{LDH}$ release (i.e. \% release LDH activity in SCH66336-treated cells/maximum LDH activity in cell lysate).

\section{Measurement of cAMP}

To investigate the effect of SCH66336 on agonist-mediated cAMP generation, cells were pre-incubated in the presence or absence of SCH66336 (10 nM) for $16 \mathrm{~h}$ before harvesting. For concentration-response studies, cells were pre-incubated for $16 \mathrm{~h}$ in the presence of SCH66336 (0-10 nM). For time-course assays, cells were pre-incubated for $0-24 \mathrm{~h}$ in the presence of SCH66336 $(5 \mathrm{nM})$. Thereafter, non-viable cells were removed, and cAMP assays were preformed as described previously [11].

\section{Measurement of $\left[\mathrm{Ca}^{2+}\right]_{i}$ (intracellular $\left.\left[\mathrm{Ca}^{2+}\right]\right)$ mobilization}

Measurements of $\left[\mathrm{Ca}^{2+}\right]_{\mathrm{i}}$ mobilization in fura 2/AM-preloaded cells was carried out essentially described as previously [11]. Cells were pre-incubated for $16 \mathrm{~h}$ with either SCH66336 (1000 nM) or with the vehicle, $0.0001 \%$ DMSO. For concentration-response studies, cells were pre-incubated with SCH66336 (0-1000 nM) for $16 \mathrm{~h}$. In separate experiments, to examine the concentration effect of SCH66336 on IP-mediated counter-regulation of TP-mediated signalling, HEK.TP $\alpha$ cells and HEK.TP $\beta$ cells, transiently transfected with pCMV:G $\alpha_{\mathrm{q}}$, were pre-incubated in the presence or absence of SCH66336 (1000 nM) for $16 \mathrm{~h}$. For concentrationresponse studies, cells were pre-incubated with SCH66336 $(0-1000 \mathrm{nM})$ for $16 \mathrm{~h}$. Thereafter, $\left[\mathrm{Ca}^{2+}\right]_{\mathrm{i}}$ mobilization in fura 2/AM-preloaded cells was measured essentially as described previously [11].

\section{Immunofluorescence microscopy}

Immunofluorescence analysis was performed essentially as described previously [12]. Cells were pre-incubated for $24 \mathrm{~h}$ with either SCH66336 $(1000 \mathrm{nM})$ or with the vehicle, $0.0001 \%$ DMSO. Thereafter, cells were stimulated with cicaprost $(1 \mu \mathrm{M}$; $4 \mathrm{~h}$ ) or with vehicle (Tris-buffered saline), serving as a control. Immunofluorescent images, captured with the appropriate FITC filter, were monitored using an Axioplan 2 Fluorescent Microscope (Zeiss Vision GmbH, Cologne, Germany).

\section{Agonist-induced IP internalizations}

For quantification of agonist-induced IP internalization, ELISAs were performed essentially as described previously [12]. Cells were incubated with $1 \mu \mathrm{M}$ SCH66336 or with vehicle $(0.0001 \%$ DMSO) for $24 \mathrm{~h}$. Internalizations of HA-tagged IP receptors were quantified as the mean percentage (\%) of cellsurface IP in agonist-treated cells relative to vehicle (non-treated) cells \pm S.E.M., where control, vehicle-treated cells were assigned a value of $100 \%$.

\section{Immunoblot analysis of HDJ-2 isoprenylation}

To investigate the effect of SCH66336 on HDJ-2 isoprenylation, cells were incubated with SCH66336 $(0-10 \mathrm{nM})$ or with the vehicle $(0.0001 \%$ DMSO) for $24 \mathrm{~h}$. For time-dependent-response studies, cells were incubated with SCH66336 $(5 \mathrm{nM})$ or with the vehicle $(0.0001 \%$ DMSO) for $24 \mathrm{~h}$. Thereafter, cells were harvested and aliquots of whole-cell protein $(25 \mu \mathrm{g})$ were analysed for HDJ-2 expression essentially as described previously [16]. Quantification of farnesylated and non-farnesylated HDJ-2 protein fractions was performed by densitometric scanning using a GelWorks 1D Intermediate UVP gel documentation system.
Percentage inhibition of HDJ-2 farnesylation was determined by comparing the signal in the non-farnesylated band with the overall intensities of farnesylated plus non-farnesylated bands. The levels of non-farnesylated protein in vehicle-treated cells were assigned a value of zero.

\section{In vitro transcription, translation and isoprenylation}

Prior to in vitro transcription, $\mathrm{pHM}: \mathrm{Ras}^{\mathrm{WT}}$, ${ }^{\mathrm{pHM}}: \mathrm{Ras}^{\mathrm{CSLC}}$, $\mathrm{pHM}$ : $\operatorname{Ras}^{\mathrm{SSLC}}$, pHM:Ras ${ }^{\mathrm{CVL}}$ and $\mathrm{pHM}: \mathrm{Ras}^{\mathrm{CVIM}}$ plasmids were linearized by digestion with $E c o$ RI. The linearized plasmids $(4 \mu \mathrm{g})$ were transcribed with T7 RNA polymerase as previously described [14]. In vitro translation of the RNA transcripts was performed in a methionine-deficient rabbit reticulocyte lysate system (Promega) according to manufacturer's recommendations. Standard reactions $(25 \mu \mathrm{l})$ containing $2.5 \mu \mathrm{g}$ of RNA and either $20 \mu \mathrm{Ci}$ of $\mathrm{L}-\left[{ }^{35} \mathrm{~S}\right]$ methionine, $25 \mu \mathrm{Ci}$ of $\left[{ }^{3} \mathrm{H}\right] \mathrm{MVA}, 1.25 \mu \mathrm{Ci}$ of $\left[{ }^{3} \mathrm{H}\right] \mathrm{FPP}$ (farnesyl pyrophosphate) or $1.25 \mu \mathrm{Ci}\left[{ }^{3} \mathrm{H}\right] \mathrm{GGPP}$ (geranylgeranyl pyrophosphate) were translated essentially as described previously [14]. To investigate the effect of SCH66336 on isoprenylation of the CAAX motif in vitro, RNA transcripts were translated in the presence of $\left[{ }^{3} \mathrm{H}\right] \mathrm{MVA} \pm \mathrm{SCH} 66336(25 \mathrm{nM})$, $\left[{ }^{3} \mathrm{H}\right] \mathrm{FPP} \pm \mathrm{SCH} 66336 \quad(25 \mathrm{nM})$ or $\left[{ }^{3} \mathrm{H}\right] \mathrm{GGPP} \pm \mathrm{SCH} 66336$ (25 $\mathrm{nM})$, as described previously [14]. Proteins from each reaction were subjected to SDS/PAGE, followed by electroblotting on to PVDF membranes. Blots were soaked in Amplify (Amersham Biosciences) for $30 \mathrm{~min}$, followed by autoradiography using Kodak Xomat XAR film at $-70{ }^{\circ} \mathrm{C}$ for at least 21 days for ${ }^{3} \mathrm{H}$ exposures, or for $16 \mathrm{~h}$ for $\left[{ }^{35} \mathrm{~S}\right]$ methionine exposures.

\section{In vivo isoprenylation in whole cells}

To investigate the ability of SCH66336 to interfere with isoprenylation of Ha-Ras ${ }^{\mathrm{WT}}$, Ha-Ras ${ }^{\mathrm{CSLC}}$, Ha-Ras ${ }^{\mathrm{SSLC}}$, Ha-Ras ${ }^{\mathrm{CVLL}}$ and Ha-Ras ${ }^{\mathrm{CVIM}}$ in vivo, metabolic labelling of whole cells was performed essentially as described previously [11]. Cells were pre-incubated for $16 \mathrm{~h}$ with either $250 \mu \mathrm{Ci}\left[{ }^{3} \mathrm{H}\right] \mathrm{MVA}$ plus $1 \mu \mathrm{M}$ SCH66336, or with $250 \mu \mathrm{Ci}\left[{ }^{3} \mathrm{H}\right] \mathrm{MVA}$ plus an equivalent volume of the drug vehicle $(0.0001 \%$ DMSO). Thereafter, cells were harvested and aliquots of whole cell protein $(60 \mu \mathrm{g})$ were resolved by SDS/PAGE and electroblotted on to PVDF membranes. The remaining protein from each transfection $(\approx 500 \mu \mathrm{g})$ was subjected to immunoprecipitation using the anti-(HA 101R) serum, as described previously [11]. Blots were then permeated in Amplify (Amersham Biosciences) and subjected to fluorography, as described previously [11].

\section{Data analysis}

Statistical analysis was carried out using the unpaired Student's $t$ test using the GraphPad Prism V2.0 program (GraphPad Software Inc., San Diego, CA, U.S.A.). $P$ values $\leqslant 0.05$ were considered to indicate a statistically significant difference.

\section{RESULTS}

SCH66336 is a selective FTase inhibitor undergoing clinical trials as a chemotherapeutic agent for the treatment of a variety of solid tumours [5] but, to date, has not yet been extensively tested against certain other proteins known to undergo farnesylation, such as the IP. Thus in the present study we investigated the potential effects of SCH66336 on isoprenylation and function of hIP and mIP stably expressed in HEK-293 cells, or by the hIP endogenously expressed in HEL92.1.7 ('HEL', human erythroleukaemia) cells.

Initially, the potential effect of SCH66336 on the cell viability of HEK-293 and HEL cells cultured in a range of SCH66336 concentrations was evaluated. While the level of SCH66336-induced 


\section{Table 1 Cytotoxic effects of SCH66336}

HEK-293 and HEL92.1.7 (HEL) cells were pre-incubated with SCH66336 (1 nM, $20 \mathrm{nM}$ or $1000 \mathrm{nM})$ or, as controls, with the drug-vehicle [0.0001\% (v/v) DMSO] for $24 \mathrm{~h}$ SCH66336-induced cytotoxicity was determined by measuring LDH release, and was expressed as a percentage of maximum LDH release determined in the presence of Triton X-100 (\% cytotoxicity), as outlined in the Experimental section.

\begin{tabular}{lllll}
\hline & \multicolumn{4}{l}{ Percentage cytotoxicity (\%) } \\
\cline { 3 - 5 } Cell type & {$[$ SCH66336] $(\mathrm{nM}) \ldots$} & 1 & 20 & 1000 \\
\hline HEK-293 & & $2.6 \pm 0.8$ & $8.2 \pm 1.4$ & $18.6 \pm 2.4$ \\
HEL & $2.2 \pm 0.4$ & $5.5 \pm 0.2$ & $25.6 \pm 2.1$ \\
\hline
\end{tabular}

cell cytotoxicity was low, it became significant at $20 \mathrm{nM}$ (Table 1), with $75.2 \pm 7.5 \%$ of HEK-293 cells and $75.2 \pm 1.4 \%$ of HEL cells remaining viable following $24 \mathrm{~h}$ exposure to $1000 \mathrm{nM}$ SCH66336. Similar data were generated in the clonal HEK.hIP and HEK.mIP cell lines stably overexpressing the HA-tagged forms of hIP and mIP respectively (results not shown). Hence, for all subsequent studies, measurement of ligand binding and intracellular signalling by the IPs was performed on viable cells only.

Thereafter, the effect of SCH66336 on intracellular signalling by the IP expressed in HEK.hIP and HEK.mIP cells, and in HEL cells was investigated by examining its effect on agonist-induced cAMP generation in response to the selective IP agonist cicaprost [7]. As a control, the effect of SCH66336 on cAMP generation by the non-isoprenylated $\mathrm{G}_{\mathrm{s}}$ /adenylate cyclase-coupled $\beta_{2} \mathrm{AR}$ in response to stimulation of HEK. $\beta_{2} \mathrm{AR}$ cells with isoproterenol was also examined. Whereas HEK.hIP and HEK.mIP cells exhibited significant cicaprost-induced increases in cAMP, pre-incubation of those cells with $10 \mathrm{nM} \mathrm{SCH} 66336$ for $16 \mathrm{~h}$ reduced cAMP generation to levels that were not significantly different from those generated by the non-transfected parental HEK-293 cells (Figure 1A). From concentration-response studies, $\mathrm{IC}_{50}$ values for SCH66336 in HEK.hIP (Figure 1B) and HEK.mIP (Figure 1C) cells were determined to be $0.27 \mathrm{nM}$ and $0.43 \mathrm{nM}$ respectively, while the extent of maximal inhibition at $10 \mathrm{nM} \mathrm{SCH66336}$ was found to be $71.4 \pm 7.1 \%(P \leqslant 0.0001)$ and $74.4 \pm 9.4 \%$ $(P \leqslant 0.0001)$ for hIP and mIP respectively (Figures $1 \mathrm{~A}-1 \mathrm{C})$. Consistent with that observed in the HEK.hIP and HEK.mIP cell lines, agonist stimulation of hIP endogenously expressed in HEL cells exhibited significant fold increases in cicaprost-induced cAMP generation over basal levels (Figure 1A). Moreover, preincubation of HEL cells with SCH66336 (16 h) significantly reduced cicaprost-induced cAMP generation in a concentrationdependent manner ( $\mathrm{IC}_{50} 0.62 \mathrm{nM}$; Figures $1 \mathrm{~A}$ and 1D). From concentration-response studies, an $\mathrm{IC}_{50}$ of $0.62 \mathrm{nM}$ SCH66336 was determined, while the extent of maximal inhibition of hIP signalling at $10 \mathrm{nM} \mathrm{SCH66336}$ was $80.3 \pm 1.2 \%$ (Figures $1 \mathrm{~A}$ and $1 \mathrm{D} ; P \leqslant 0.0001)$. Whereas stimulation of the control HEK. $\beta_{2} \mathrm{AR}$ cells with isoproterenol $(10 \mu \mathrm{M})$ produced a $6.9 \pm 0.21$-fold increase in cAMP generation over basal levels, in contrast with those studies involving the IPs, pre-treatment of HEK. $\beta_{2} \mathrm{AR}$ cells with SCH66336 did not significantly affect the levels of isoproterenol-induced cAMP generation throughout the range of SCH66336 concentrations utilized (Figures 1A and 1E; $P \geqslant 0.5$ ).

\section{The effect of SCH66336 on IP-mediated $\left[\mathrm{Ca}^{2+}\right]_{i}$ mobilization}

Although the IP is mainly coupled to Gs/adenylate cyclase activation, it also exhibits efficient coupling to $\mathrm{G}_{\mathrm{q}} / \mathrm{PLC} \beta$ (phospholipase $\mathrm{C} \beta$ ) activation, with concomitant rises in $\left[\mathrm{Ca}^{2+}\right]_{i}$ in certain cell types $[11,12]$. Hence, in the present study, we extended our investigations to examine the effect of SCH66336 on cicaprost-induced $\left[\mathrm{Ca}^{2+}\right]_{\mathrm{i}}$ mobilization by hIP and mIP stably overexpressed in HEK-293 cells and in HEL cells. As a control for a nonisoprenylated $\mathrm{G}_{\mathrm{q}} / \mathrm{PLC} \beta$-coupled GPCR (G-protein-coupled receptor), the effect of SCH66336 on agonist-induced $\left[\mathrm{Ca}^{2+}\right]_{\mathrm{i}}$ mobilization by the $\beta$ isoform of TP (TP $\beta$ ) was investigated. Consistent with previous reports $[11,12,15]$, stimulation of both HEK.hIP (Figure $2 \mathrm{~A} ; \Delta\left[\mathrm{Ca}^{2+}\right]_{\mathrm{i}}=130 \pm 3.54 \mathrm{nM}$ ) and HEK.mIP (Figure $2 \mathrm{C} ; \Delta\left[\mathrm{Ca}^{2+}\right]_{\mathrm{i}}=157 \pm 17.4 \mathrm{nM}$ ) cells showed efficient $\left[\mathrm{Ca}^{2+}\right]_{\mathrm{i}}$ mobilization in response to the IP agonist cicaprost $(1 \mu \mathrm{M})$. Pre-incubation of cells with SCH66336 ( $1 \mu \mathrm{M}$ for $16 \mathrm{~h})$ significantly reduced cicaprost-induced $\left[\mathrm{Ca}^{2+}\right]_{\mathrm{i}}$ mobilization by the hIP (Figure $2 \mathrm{~A} ; \Delta\left[\mathrm{Ca}^{2+}\right]_{\mathrm{i}}=48.3 \pm 4.0 \mathrm{nM}, p \leqslant 0.0001$ ) and the $\mathrm{mIP}$ (Figure $2 \mathrm{C} ; \Delta\left[\mathrm{Ca}^{2+}\right]_{\mathrm{i}}=59.7 \pm 3.2 \mathrm{nM}, P=0.0006$ ). The $\mathrm{IC}_{50}$ for inhibition of cicaprost-mediated signalling in HEK.hIP cells and HEK.mIP cells was $34.6 \mathrm{nM}$ SCH66336 (Figure 2B) and $26.6 \mathrm{nM}$ SCH66336 (Figure 2D), respectively. Moreover, the extent of maximal inhibition using $1 \mu \mathrm{M}$ SCH66336 was $62.9 \pm 3.0 \%$ and $62.0 \pm 5.5 \%$ for the hIP and $\mathrm{mIP}$ respectively, relative to that mobilized in the absence of SCH66336 (Figures 2A and 2C). Stimulation of the hIP endogenously expressed in HEL cells also exhibited efficient cicaprost-induced $\left[\mathrm{Ca}^{2+}\right]_{\mathrm{i}}$ mobilization (Figure 2E; $\Delta\left[\mathrm{Ca}^{2+}\right]_{\mathrm{i}}=$ 98.5 $\pm 4.5 \mathrm{nM}$ ), consistent with hIP coupling to $\mathrm{G} \alpha_{\mathrm{q}}$ in megakaryocytic lineages, as reported previously [15]. Pre-incubation of HEL cells with SCH66336 ( $1 \mu \mathrm{M}$ for $16 \mathrm{~h})$ significantly reduced cicaprost-induced $\left[\mathrm{Ca}^{2+}\right]_{\mathrm{i}}$ mobilization (Figure 2E; $\left.\Delta\left[\mathrm{Ca}^{2+}\right]_{\mathrm{i}}=29.6 \pm 12.6 \mathrm{nM}, P=0.0354\right)$ in a concentrationdependent manner $\left(\mathrm{IC}_{50}=43.7 \mathrm{nM}\right.$; Figure $\left.2 \mathrm{~F}\right)$, whereas the extent of maximal inhibition observed at $1 \mu \mathrm{M}$ SCH66336 was $73.2 \pm 7.1 \%$ (Figure $2 \mathrm{E}$ ). In contrast, while stimulation of the control HEK.TP $\beta$ cells, transiently co-transfected with $\mathrm{G} \alpha_{\mathrm{q}}$, showed efficient $\left[\mathrm{Ca}^{2+}\right]_{\mathrm{i}}$ mobilization in response to the $\mathrm{TXA}_{2}$ mimetic U46619 $\left(1 \mu \mathrm{M}\right.$; Figure $\left.2 \mathrm{G}, \Delta\left[\mathrm{Ca}^{2+}\right]_{\mathrm{i}}=167 \pm 6.9 \mathrm{nM}\right)$, pre-incubation of those cells with SCH66336 $(1 \mu \mathrm{M}$ for $16 \mathrm{~h}) \mathrm{did}$ not significantly reduce U46619-mediated $\left[\mathrm{Ca}^{2+}\right]_{\mathrm{i}}$ mobilization (Figure $2 \mathrm{H} ; \Delta\left[\mathrm{Ca}^{2+}\right]_{\mathrm{i}}=157 \pm 5.5 \mathrm{nM}, P=0.3535$ ).

\section{The effect of SCH66336 on ligand binding properties of the IP}

To exclude the possibility that the observed reductions in IP-mediated signalling might be indirect, such as due to an overall reduction in the level of IP expression rather than due to a functional impairment of IP coupling to $\mathrm{G} \alpha_{\mathrm{s}}$ /adenylate cyclase or $\mathrm{G} \alpha_{\mathrm{q}} / \mathrm{PLC} \beta$, the effect of SCH66336 on the radioligand binding properties of the hIP and mIP was investigated (Table 2). Preincubation of cells with SCH66336 $(1 \mu \mathrm{M}$ for $16 \mathrm{~h})$ did not significantly affect $\left[{ }^{3} \mathrm{H}\right]$ iloprost binding by the IPs either stably overexpressed in HEK-293 cells or in HEL cells (Table 2). Consistent with this, $\left[{ }^{3} \mathrm{H}\right] \mathrm{CGP}-12177$ binding by the $\beta_{2} \mathrm{AR}$ and $\left[{ }^{3} \mathrm{H}\right] \mathrm{SQ} 29,548$ binding by the TP $\alpha$ or, indeed, the TP $\beta$ isoform of the TP overexpressed in HEK-293 cells was not significantly impaired by SCH66336 ( $1 \mu \mathrm{M}, 16 \mathrm{~h})$, being directly comparable with those levels observed in the absence of SCH66336 (Table 2).

\section{The effect of SCH66336 on IP agonist-mediated internalization}

The IP has been widely reported to undergo rapid agonist-induced internalization and desensitization following activation, and such desensitizations are believed to represent important mechanisms whereby the responses to the potent autocoid prostacyclin is dynamically regulated [17]. Through the generation of an isoprenylation-defective hIP ${ }^{\text {SSLC }}$, we have recently established that, while both the hIP and hIP ${ }^{\text {SSLC }}$ undergo agonist-induced internalization, the kinetics and extent of hIP ${ }^{\text {SSLC }}$ internalization was impaired 


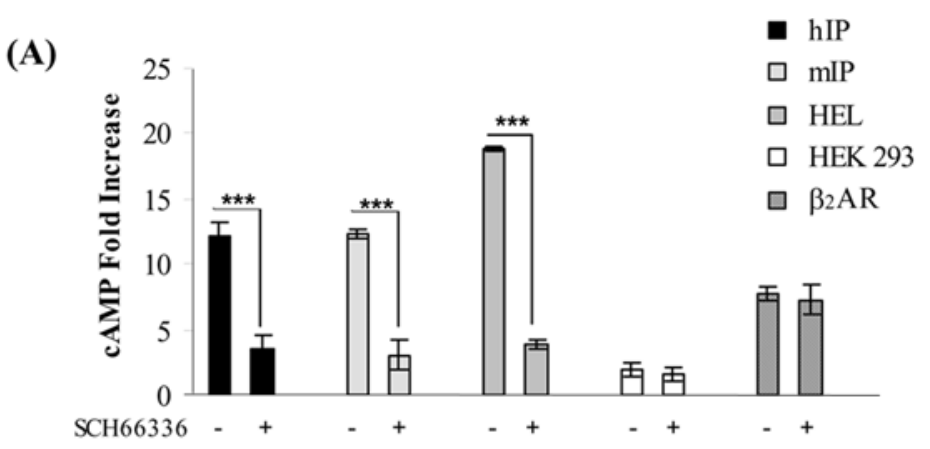

(B)

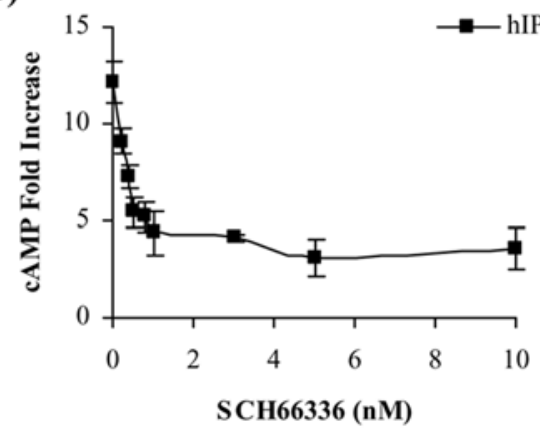

(C)

(D)

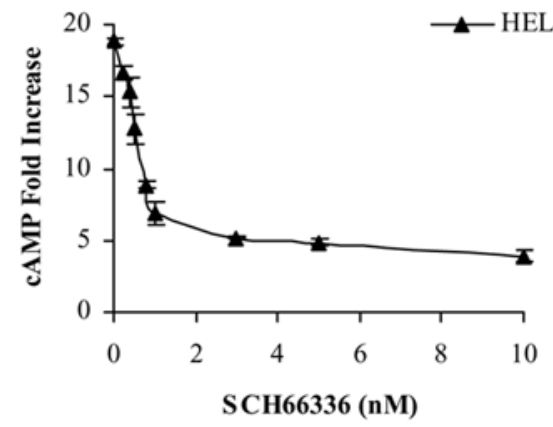

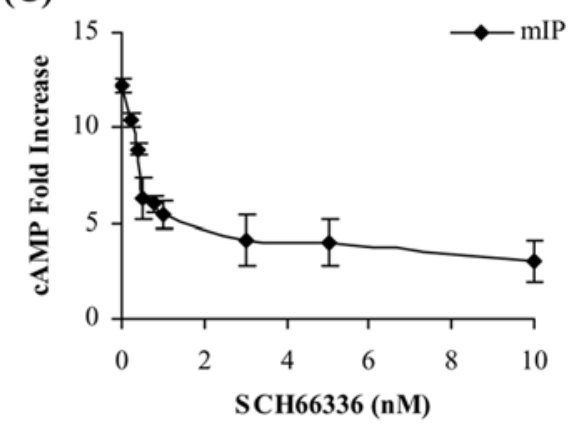

(E)

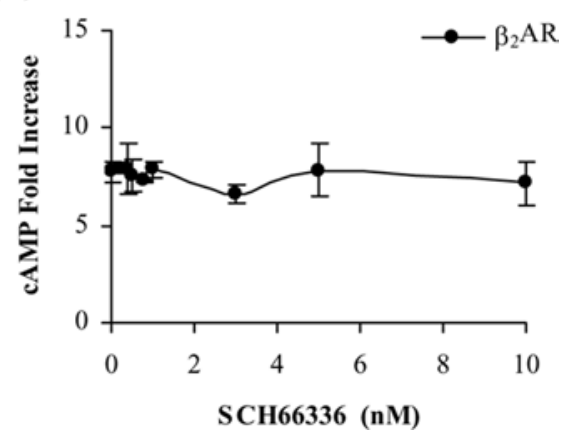

Figure 1 Effect of SCH66336 on IP-mediated cAMP generation

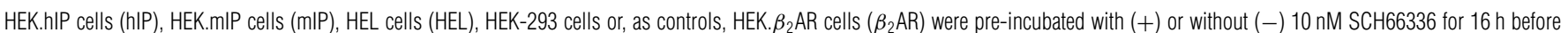

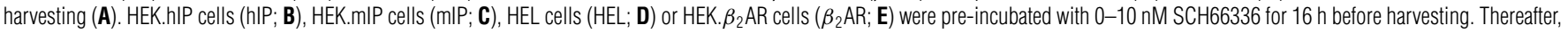
cells were stimulated with $1 \mu \mathrm{M}$ cicaprost or, in the case of the HEK. $\beta_{2}$ AR cells, with $10 \mu \mathrm{M}$ isoproterenol. In each case, basal cAMP levels were determined by exposing the cells to the vehicle HBS under identical incubation conditions. Levels of cAMP produced in ligand-stimulated cells, relative to basal cAMP levels, in vehicle-treated cells were expressed as fold stimulation of basal (fold increase in CAMP + S.E.M, $n=4$ ). The asterisks $\left(^{*}\right)$ in $(\mathbf{A})$ indicate that the level of cicaprost-mediated cAMP generation was significantly reduced in the presence of SCH66336 compared with vehicle-treated cells, where ${ }^{* \star *}$ indicates $P \leqslant 0.001$. Basal levels of CAMP in HEK.hIP, HEK.mIP, HEL, HEK-293 and in HEK. $\beta_{2}$ AR cells were $0.57 \pm 0.07,0.22 \pm 0.01,0.99 \pm 0.09,0.41 \pm 0.06$ and $0.36 \pm 0.03 \mathrm{nmol} / \mathrm{mg}$ of cell protein respectively.

relative to that of wild-type hIP, implying that farnesylation of the IP is also required for efficient agonist-induced IP desensitization and internalization [12]. Thus, in the current study, the possible effects of SCH66336 on cicaprost-induced IP internalization were investigated, as assessed by indirect immunofluorescence microscopy and ELISA. Initially, immunofluorescence microscopy was performed on HEK.hIP cells and, as a control, on HEK-293 cells under non-permeabilizing conditions (Figure 3A). The hIP was abundantly expressed on the plasma membrane of HEK.hIP cells, as evidenced by strong immunostaining of cells (Figure 3Ai). In contrast, the control HEK293 cells showed no immunofluorescent staining (Figure 3Aiv). Consistent with previous reports [12], the hIP underwent cicaprost-induced $(1 \mu \mathrm{M}$ for $4 \mathrm{~h})$ internalization, as evidenced by a decrease in surface expression of the HA-epitope-tagged hIP compared with that of vehicle-treated cells (Figure 3Aii). However, pre-incubation of HEK.hIP cells with SCH66336 (1 $\mu \mathrm{M}$ for $24 \mathrm{~h}$ ) significantly reduced the extent of cicaprost-induced hIP internalization, as evidenced by the strong immunofluorescent staining on the plasma membrane (Figure 3Aiii).

Thereafter, the effect of SCH66336 (1 $\mu \mathrm{M}$ for $24 \mathrm{~h})$ on cicaprost-induced IP internalization was quantified further using an ELISA-based internalization assay [12]. Consistent with previous reports [12], stimulation of hIP with cicaprost induced a time-dependent internalization of the receptor, as monitored by the loss of surface expression of HA-epitope-tagged IP on the plasma membrane in non-permeabilized HEK.hIP cells (Figure $3 \mathrm{~B} ; 53.5 \pm 1.6 \%$ cell-surface hIP receptor remaining relative to vehicle-treated cells following a $4 \mathrm{~h}$ incubation with cicaprost). However, pre-incubation of the HEK.hIP cells with SCH66336 
(A)

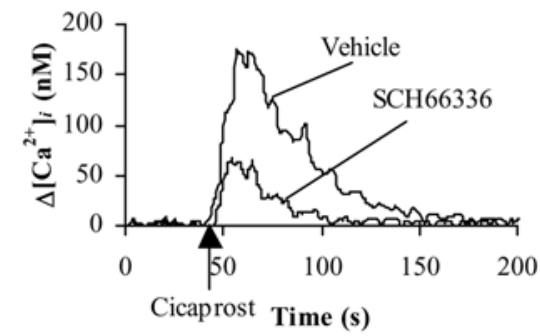

(C)

(E)

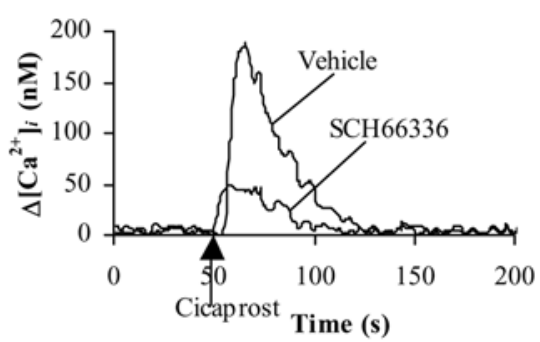

(G)
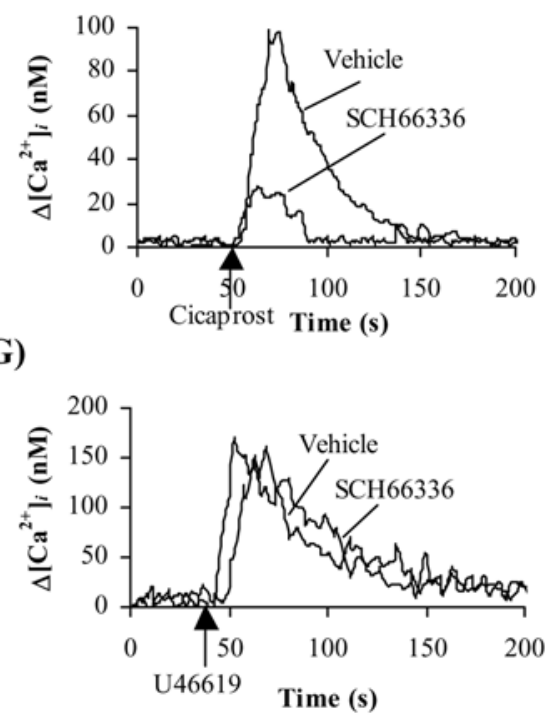

(B)

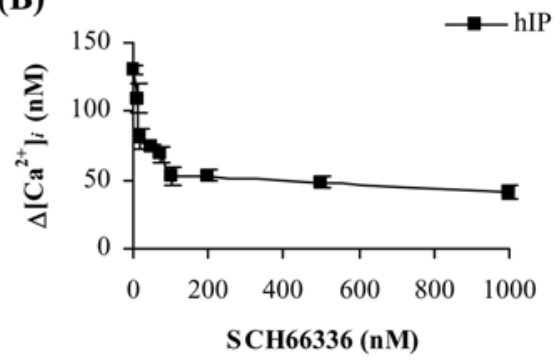

(D)

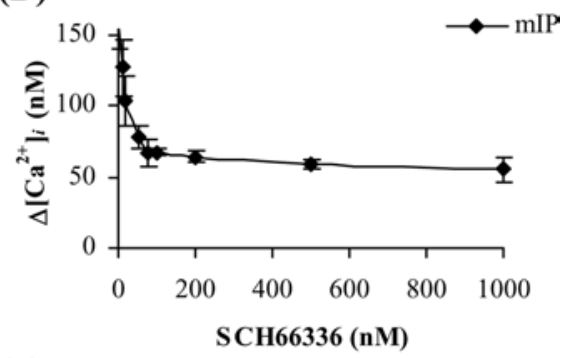

(F)

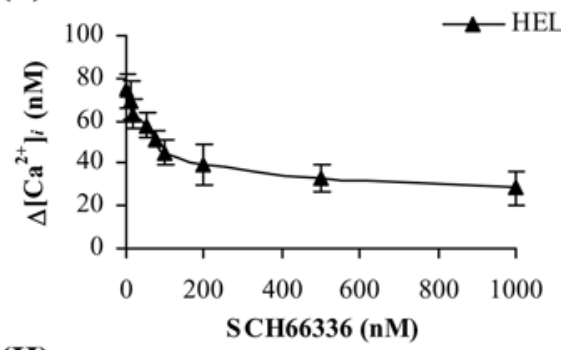

(H)

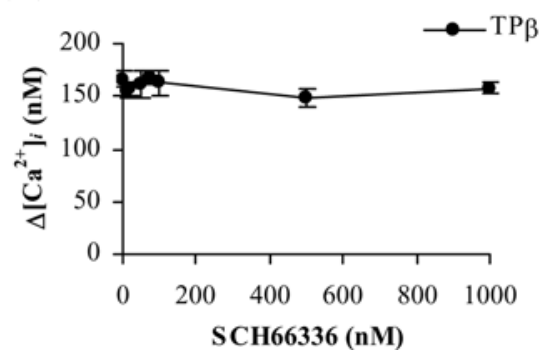

Figure 2 Effect of SCH66336 on IP-mediated $\left[\mathrm{Ca}^{2+}\right]_{\mathrm{i}}$ mobilization

HEK.hIP cells (A and B), HEK.mIP cells (C and D), HEL cells (E and $\mathbf{F})$ and, as controls, HEK.TP $\beta$ cells ( $\mathbf{G}$ and $\mathbf{H}$ ) were pre-incubated with either $1000 \mathrm{nM}$ SCH66336 or $0.0001 \%$ DMSO (vehicle) $(\mathbf{A}, \mathbf{C}, \mathbf{E}$ and $\mathbf{G})$ or, alternatively, with 0-1000 nM SCH66336 (B, D, F and $\mathbf{H})$ for $16 \mathrm{~h}$ before harvesting. Cells, preloaded with fura2/AM, were stimulated with $1 \mu \mathrm{M}$ cicaprost $(\mathbf{A}, \mathbf{C}$ and $\mathbf{E})$ or with $1 \mu \mathrm{M} \cup 46619(\mathbf{G})$ at times indicated by the arrows. Data presented in $(\mathbf{A}),(\mathbf{C}),(\mathbf{E})$ and $(\mathbf{G})$ are representative of at least four independent experiments, and are plotted as changes $(\mathrm{nM})$ in $\Delta\left[\mathrm{Ca}^{2+}\right]_{\mathrm{i}} \pm$ S.E.M $(n=4)$ as a function of time $(\mathrm{S})$. In panels $(\mathbf{B}),(\mathbf{D}),(\mathbf{F})$ and $(\mathbf{H})$, mean changes $(n M)$ in $\left[\mathrm{Ca}^{2+}\right]_{i}$ mobilization $\left(\Delta\left[\mathrm{Ca}^{2+}\right]_{i} \pm \mathrm{S} . \mathrm{E} . \mathrm{M}, n=4\right)$ are plotted as a function of SCH66336 concentration $(\mathrm{nM})$.

( $1 \mu \mathrm{M}$ for $24 \mathrm{~h})$ significantly impaired cicaprost-induced internalization of the hIP (Figure 3B; $82.3 \pm 1.6 \%$ cell-surface hIP receptor remaining relative to vehicle-treated cells following $4 \mathrm{~h}$; $P<0.0001)$.

\section{The effect of SCH66336 on IP-mediated desensitization of TP signalling}

We have previously established that the $\operatorname{TP} \alpha$, but not the $\operatorname{TP} \beta$, isoform of TP is subject to IP-induced desensitization/counterregulation of signalling that occurs through a mechanism involving direct PKA (cAMP-dependent protein kinase) phosphorylation of TP $\alpha$ within its unique C-tail domain, whereby $\mathrm{Ser}^{329}$ was identified as the target residue for PKA phosphorylation and receptor desensitization [13]. Thus, in view of its inhibitory effect on IP signalling reported herein, we sought to investigate the effect of SCH66336 on IP-mediated desensitization or counter-regulation of TP receptor responses. Thus, to this end, we examined the ability SCH663366 to regulate cicaprost-induced desensitization of TP $\alpha$ - and, as a control, TP $\beta$-mediated increases in $\left[\mathrm{Ca}^{2+}\right]_{\mathrm{i}}$ mobilization in response to their stimulation with $\mathrm{U} 46616$. Consistent with previous reports [13], stimulation of both $\mathrm{TP} \alpha$ and $\operatorname{TP} \beta$, stably overexpressed in HEK.TP $\alpha$ and HEK.TP $\beta$ cells respectively, showed efficient U46619-induced $\left[\mathrm{Ca}^{2+}\right]_{\mathrm{i}}$ mobilization (Figures $4 \mathrm{~A}$ and $4 \mathrm{~B} ; \Delta\left[\mathrm{Ca}^{2+}\right]_{\mathrm{i}}=170 \pm 21.8 \mathrm{nM}$ and $\Delta\left[\mathrm{Ca}^{2+}\right]_{\mathrm{i}}=204 \pm 7.9 \mathrm{nM}$ for $\mathrm{TP} \alpha$ and $\mathrm{TP} \beta$ respectively). Whereas stimulation of HEK.TP $\alpha$ cells with cicaprost $(1 \mu \mathrm{M})$ failed to induce a rise $\left[\mathrm{Ca}^{2+}\right]_{\mathrm{i}}$, it significantly reduced $\left[\mathrm{Ca}^{2+}\right]_{\mathrm{i}}$ 


\section{Table 2 Radioligand binding assays}

(a) Radioligand binding assays were performed on crude cell membrane fractions (P100; $50-100 \mu \mathrm{g} /$ assay) in the presence of $4 \mathrm{nM}\left[{ }^{3} \mathrm{H}\right]$ iloprost at $30^{\circ} \mathrm{C}$ for $60 \mathrm{~min}$. (b) Radioligand binding assays were performed on whole cells (50-100 $\mu \mathrm{g}$ /assay) in the presence of $25 \mathrm{nM}$ $\left.{ }^{3} \mathrm{H}\right] \mathrm{CGP}-12177$ at $14^{\circ} \mathrm{C}$ for $3 \mathrm{~h}$. (c) Radioligand binding assays were performed on whole cells in the presence of $20 \mathrm{nM}\left[{ }^{3} \mathrm{H}\right] \mathrm{SQ} 29,548$ at $30^{\circ} \mathrm{C}$ for $30 \mathrm{~min}$. Data presented are the means \pm S.E.M $(n=3)$

(a)

\begin{tabular}{lll}
\hline Cell type & SCH66336 $(1 \mu \mathrm{M})$ & {$\left[{ }^{3} \mathrm{H}\right]$ Illoprost bound (fmol/mg of protein) } \\
\hline HEK.hIP & - & $1353 \pm 438$ \\
& + & $1206 \pm 479$ \\
HEK.mIP & - & $1362 \pm 72.1$ \\
& + & $1401 \pm 11.3$ \\
HEL & - & $87.9 \pm 22.2$ \\
& + & $95.6 \pm 38.5$ \\
HEK-293 & - & $12.0 \pm 0.59$ \\
& + & $15.2 \pm 2.23$
\end{tabular}

(b)

\begin{tabular}{llr}
\hline Cell type & SCH66336 $(1 \mu \mathrm{M})$ & {$\left[{ }^{3} \mathrm{H}\right] \mathrm{CGP}-12$} \\
\hline & & \\
HEK. $\beta_{2}$ AR & - & $329 \pm 28.3$ \\
& + & $341 \pm 50.1$ \\
HEK 293 & - & $7.82 \pm 0.56$ \\
& + & $8.65 \pm 0.44$
\end{tabular}

(c)

Cell type $\quad$ SCH66336 $(1 \mu \mathrm{M}) \quad\left[{ }^{3} \mathrm{H}\right] \mathrm{SQ29,548}$ bound (fmol/mg of protein)

\begin{tabular}{lll}
\hline & & \\
HEK.TP $\alpha$ & - & $1946 \pm 48$ \\
HEK.TP $\beta$ & + & $2070 \pm 134$ \\
& - & $1716 \pm 93.9$ \\
HEK-293 & + & $12.8 \pm 0.30$ \\
& - & $14.5 \pm 3.57$ \\
\hline
\end{tabular}

mobilization in response to secondary stimulation of cells with U46619 (Figure 4A, compare values for U46619-mediated $\left[\mathrm{Ca}^{2+}\right]_{\mathrm{i}}$ mobilization: $\Delta\left[\mathrm{Ca}^{2+}\right]_{\mathrm{i}}=170 \pm 21.8 \mathrm{nM}$ compared with $\Delta\left[\mathrm{Ca}^{2+}\right]_{\mathrm{i}}=57.7 \pm 13.9 \mathrm{nM}$ in the absence and presence of cicaprost respectively; $P=0.0124)$. Pre-incubation of HEK.TP $\alpha$ cells with SCH66336 $(1 \mu \mathrm{M})$ had no significant effect on U46619induced $\left[\mathrm{Ca}^{2+}\right]_{\mathrm{i}}$ mobilization \{Figure $4 \mathrm{C}$, compare values for U46619-mediated $\left[\mathrm{Ca}^{2+}\right]_{\mathrm{i}}$ mobilization: $\Delta\left[\mathrm{Ca}^{2+}\right]_{\mathrm{i}}=170 \pm$ $21.8 \mathrm{nM}$ (Figure 4A) compared with $\Delta\left[\mathrm{Ca}^{2+}\right]_{\mathrm{i}}=154 \pm 5.20 \mathrm{nM}$ (Figure 4C) in the absence and presence of SCH66336 respectively; $P=0.3044\}$. Conversely, pre-incubation of HEK.TP $\alpha$ cells with SCH66336 significantly reduced the level of cicaprostinduced desensitization of TP $\alpha$-mediated $\left[\mathrm{Ca}^{2+}\right]_{\mathrm{i}}$ mobilization in response to U46619 \{Figure 4C, compare values for U46619mediated $\left[\mathrm{Ca}^{2+}\right]_{\mathrm{i}}$ mobilization following pre-stimulation with cicaprost: $\Delta\left[\mathrm{Ca}^{2+}\right]_{\mathrm{i}}=57.7 \pm 13.9 \mathrm{nM}$ (Figure 4A) compared with $\Delta\left[\mathrm{Ca}^{2+}\right]_{\mathrm{i}}=155 \pm 20.7 \mathrm{nM}$ (Figure 4C) in the absence and presence of SCH66336 respectively; $P=0.6565\}$. From concentration-response studies, the $\mathrm{IC}_{50}$ value for inhibition of cicaprost-induced desensitization of TP $\alpha$ signalling was $56.1 \mathrm{nM}$ SCH66336 (Figure 4E). Consistent with previous results [13], stimulation of HEK.TP $\beta$ cells with U46619 yielded substantial rises in $\left[\mathrm{Ca}^{2+}\right]_{i}$ mobilization (Figures 4B and 4D). Stimulation of HEK.TP $\beta$ cells with cicaprost $(1 \mu \mathrm{M})$ failed to support a rise in cicaprost-induced $\left[\mathrm{Ca}^{2+}\right]_{\mathrm{i}}$ mobilization (Figures $4 \mathrm{~B}$ and 4D), and also failed to affect the level of TP $\beta$-mediated $\left[\mathrm{Ca}^{2+}\right]_{\mathrm{i}}$ mobilization in response to secondary stimulation of HEK.TP $\beta$ cells with U46619 (Figure 4B, compare values for U46619mediated $\left[\mathrm{Ca}^{2+}\right]_{\mathrm{i}}$ mobilization following pre-stimulation with cicaprost: $\Delta\left[\mathrm{Ca}^{2+}\right]_{\mathrm{i}}=204 \pm 7.9 \mathrm{nM}$ compared with $\Delta\left[\mathrm{Ca}^{2+}\right]_{\mathrm{i}}=$ $210 \pm 14.8 \mathrm{nM} ; \quad P=0.7511)$. Moreover, pre-incubation of HEK.TP $\beta$ cells with SCH66336 had no effect on the U46619induced $\left[\mathrm{Ca}^{2+}\right]_{i}$ mobilization (Figure 4D), and had no effect on the ability of cicaprost to affect $\operatorname{TP} \beta$-mediated $\left[\mathrm{Ca}^{2+}\right]_{\mathrm{i}}$ mobilization (Figures 4D and 4F). Thus U46619-induced signalling by

(A)
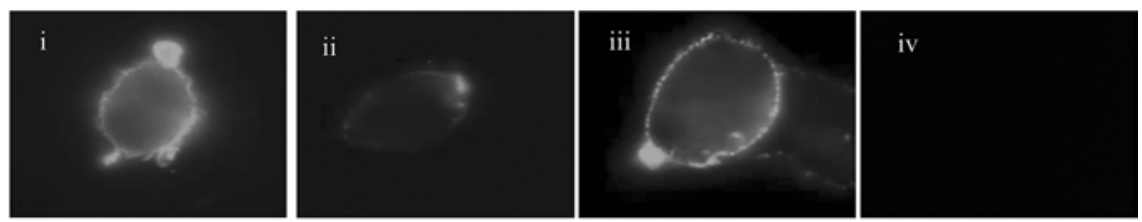

(B)

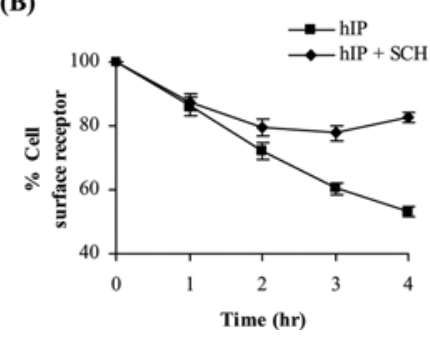

Figure 3 Effect of SCH66336 on cicaprost-mediated IP internalization

(A) HEK.hIP cells (A, i-iii) and HEK-293 cells (A, iv) were incubated with $1 \mu \mathrm{M} \mathrm{SCH66336} \mathrm{(A,} \mathrm{iii)} \mathrm{or} \mathrm{with} 0.0001 \%$ DMSO (A, i-ii) for $24 \mathrm{~h}$ before stimulation with cicaprost for $4 \mathrm{~h}(1 \mu \mathrm{M}$; A, ii-iv). Thereafter, cells were subject to indirect immunofluorescence microscopy under non-permeabilizing conditions using the anti-HA 101R primary antibody (1:2000 dilution) and FITC-labelled goat anti-mouse IgG (1:120 dilution) secondary antibody. Images captured with a FITC filter using an Axioplan 2 Fluorescent Microscope (Zeiss) represent $63 \times$ magnification, and are representative of three independent experiments. (B) HEK.hIP cells were pre-incubated for $24 \mathrm{~h}$ with $1 \mu \mathrm{M} \mathrm{SCH66336} \mathrm{(hIP}+\mathrm{SCH}$ ) or with $0.0001 \%$ DMSO (hIP). Thereafter, cells were stimulated with cicaprost $(1 \mu \mathrm{M})$ for $0-4 \mathrm{~h}$ and internalization of HA-tagged receptors was quantified by ELISA assay, as described in the Experimental section. Results are presented as the mean percentage of cell-surface receptor present in cicaprost-treated cells relative to that present in the corresponding vehicle (MEM)-treated cells \pm S.E.M. (\% cell-surface receptor \pm S.E.M.), where vehicle-treated control cells were assigned a value of $100 \%$. 
(A)

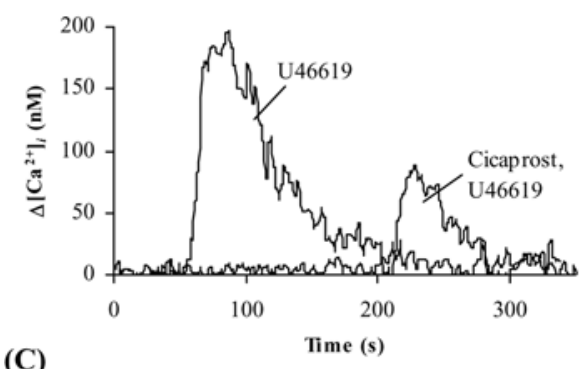

(C)

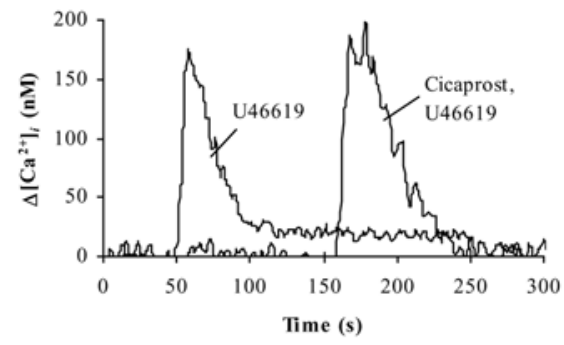

(E)

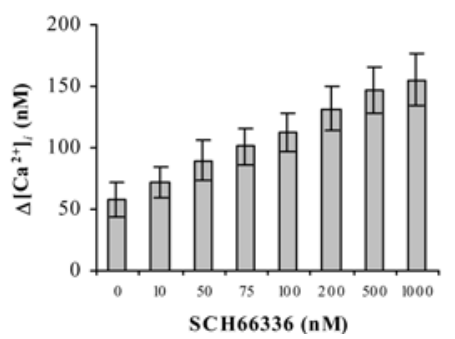

(B)

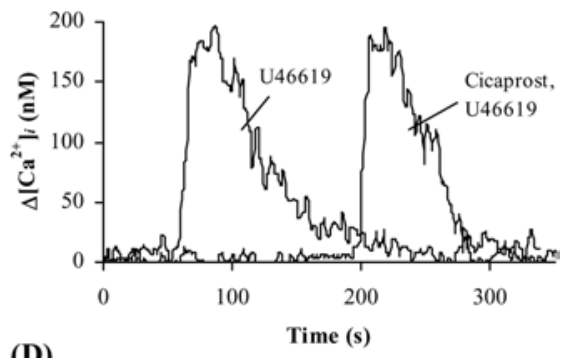

(D)

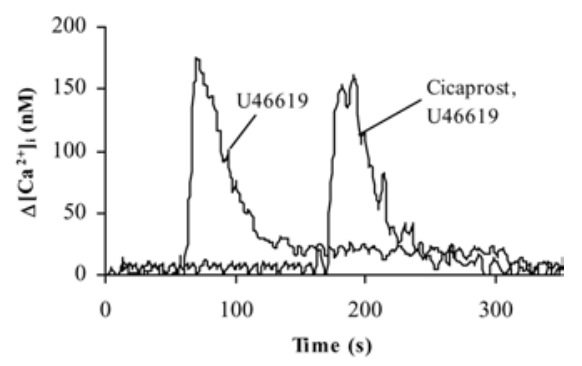

(F)

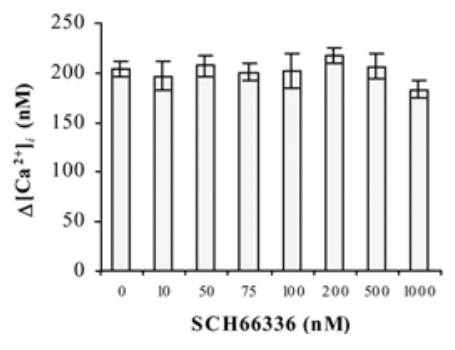

\section{Figure 4 Effect of SCH66336 on IP-mediated desensitization of TP-mediated signalling}

HEK.TP $\alpha$ cells (A, C and E) and HEK.TP $\beta$ cells (B, D and F), transiently transfected with pCMV:G $\alpha_{q}$, were pre-incubated with either the vehicle $0.0001 \%$ DMSO (A and B), with $1000 \mathrm{nM} \mathrm{SCH66336}$ (C and D) or with 0-1000 nM SCH66336 (E and F) for $16 \mathrm{~h}$ before harvesting. Cells, preloaded with fura2/AM, were stimulated with $1 \mu \mathrm{M}$ U46619 at $50 \mathrm{~s}$ (U46619) or with $1 \mu \mathrm{M}$ cicaprost at $50 \mathrm{~s}$ followed by $1 \mu \mathrm{M}$ U46619 at approx. 150-200 s (Cicaprost, U46619). Data shown in (A-D) are each representative of four independent experiments, and are plotted as changes (nM) in $\Delta\left[\mathrm{Ca}^{2+}\right]_{\mathrm{i}}$ mobilization $\left(\Delta\left[\mathrm{Ca}^{2+}\right]_{\mathrm{i}} \pm\right.$ S.E.M, $\left.n=4\right)$ as a function of time $(\mathrm{S})$. In $(\mathbf{E})$ and $(\mathbf{F})$, data are plotted as mean changes $(\mathrm{nM})$ in $\left[\mathrm{Ca}^{2+}\right]_{\mathrm{i}}$ mobilization $\left(\Delta\left[\mathrm{Ca}^{2+}\right]_{\mathrm{i}} \pm\right.$ S.E.M, $\left.n=4\right)$ as a function of SCH66336 concentration (nM).

HEK.TP $\beta$ cells was unaffected, irrespective of pre-incubation of cells in the absence or presence of SCH66336 (Figures 4D and 4F).

\section{The effect of SCH66336 on HDJ-2 isoprenylation}

The molecular chaperone protein HDJ-2 undergoes farnesylationdependent processing, and displays a mobility shift between the non-farnesylated $(49 \mathrm{kDa})$ and farnesylated $(45 \mathrm{kDa})$ species respectively, such as that displayed when farnesylation is impaired in the presence of FTIs [18]. Thus detection and measurement of the relative abundance of the farnesylated and non-farnesylated forms of HDJ-2 through immunoblot analysis is widely reported to represent a convenient method to (a) assess the potencies of FTI, and (b) in the present study, should allow for a comparison between the relative inhibitory effects of SCH66336 on the isoprenylation of the IP to that of the HDJ-2. Analysis of wholecell lysates prepared from HEK-293 cells indicated the abundant expression of HDJ-2 protein in that cell line and that, in the absence of the FTI, it is almost exclusively found in its fully processed, isoprenylated form, with no detectable expression of the slower migrating non-farnesylated species (Figure 5A). Following $24 \mathrm{~h}$ incubation of HEK-293 cells with SCH66336 (0-
$10 \mathrm{nM}$ ), there was a concentration-dependent increase in the accumulation of non-farnesylated species, and a co-ordinated reduction in the level of the faster migrating, farnesylated species (Figures $5 \mathrm{~A}$ and $5 \mathrm{C}$ ). An $\mathrm{IC}_{50}$ value for inhibition of $\mathrm{HDJ}-2$

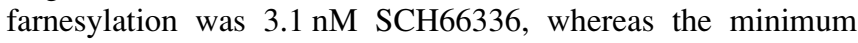
inhibitory concentration for the appearance of the slower migrating non-farnesylated form was detected at $0.8 \mathrm{nM}$ (Figures 5A and $5 \mathrm{C}$ ). To determine the pre-incubation time required for SCH66336 to inhibit HDJ-2 farnesylation, a time course assay was performed whereby HEK-293 cells were incubated in the presence of SCH66336 (5 nM) for 0-24 h (Figures 5B and 5D). Data generated showed that SCH66336 significantly affected the mobility of HDJ-2 after $4 \mathrm{~h}$, and continued to $24 \mathrm{~h}$ (Figure 5B).

\section{The effect of SCH66336 on protein isoprenylation in vitro}

Whereas all four Ras proteins serve as efficient substrates for FTase, readily undergoing farnesylation both in vitro and in vivo [4], numerous studies have demonstrated that, in the presence of FTIs, Ki-Ras 4A, Ki-Ras 4B and N-Ras, but not Ha-Ras, may become alternatively geranylgeranylated [19-21]. Thus, in order to establish whether farnesylation of the CaaX motif of the IP with the sequence -CSLC is inhibited by SCH66336, and to establish 

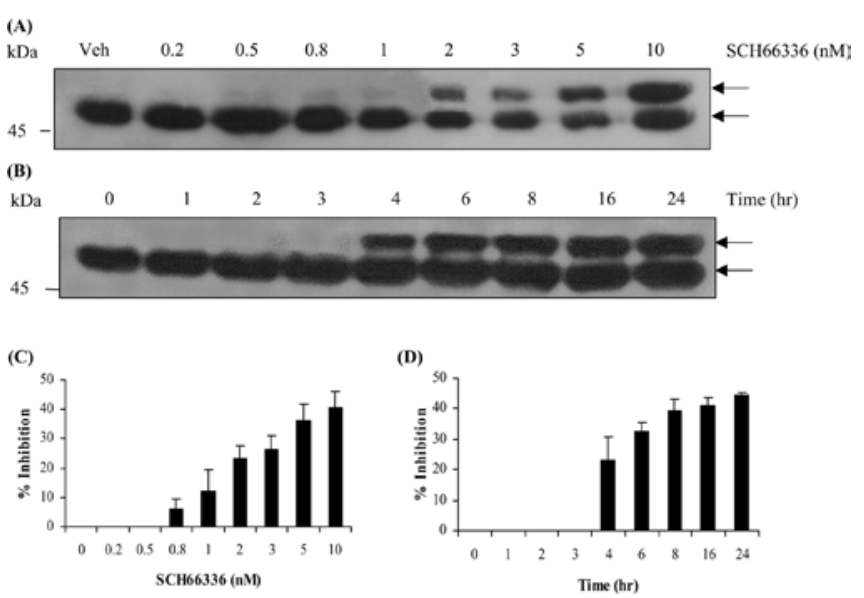

Figure 5 Effect of SCH66336 on isoprenylation and processing of HDJ-2

(A) HEK-293 cells were pre-incubated for $24 \mathrm{~h}$ with vehicle $0.0001 \%$ DMSO (Veh) or with 0-10 nM SCH66336. (B) HEK-293 cells were pre-incubated for 0-24 h with vehicle $0.0001 \%$ DMSO (Veh) or with $5 \mathrm{nM} \mathrm{SCH66336.} \mathrm{Thereafter,} \mathrm{cells} \mathrm{were} \mathrm{harvested} \mathrm{and} \mathrm{aliquots}(25 \mu \mathrm{g})$ of whole-cell protein were resolved by SDS-PAGE/immunoblotting and screened with the anti-HDJ-2 antibody, as described in the Experimental section. The arrows to the right of $(\mathbf{A})$ and $(\mathbf{B})$ indicate the slower migrating non-farnesylated species $(\approx 49 \mathrm{kDa})$ and the faster migrating, farnesylated species of HDJ-2 $(\approx 45-46 \mathrm{kDa})$, whereas the position of the $45 \mathrm{kDa}$ molecular-mass marker is indicated to the left. (C) The extent of inhibition of HDJ-2 farnesylation in (A) is plotted as the mean percentage increase of the non-farnesylated species of HDJ-2 detected in the presence of increasing concentrations of SCH66336 relative to that present in vehicle-treated cells (\% inhibition \pm S.E.M, $n=4$ ). (D) The extent of inhibition of HDJ-2 farnesylation in (B) is plotted as the mean percentage increase of the non-farnesylated species of HDJ-2 detected in the presence of $5 \mathrm{nM} \mathrm{SCH66336}$ at various time points relative to that present in vehicle-treated cells (\% inhibition \pm S.E.M., $n=4$ )

whether this motif is subject to alternative geranylgeranylation in the presence of SCH66336, similar to that seen with N-Ras, KiRas 4A and Ki-Ras 4B, we generated a series of chimaeric Ha-Ras mutants in which we directly replaced the -CaaX motif sequence of wild-type Ha-Ras (-CVLS, corresponding to residues 186-189) with that of IP (-CSLC) to generate Ha-Ras ${ }^{\mathrm{CSLC}}$. Moreover, as controls, other chimaeric Ha-Ras mutants were created by directly replacing the -CaaX motif sequence of Ha-Ras ${ }^{\mathrm{WT}}$ (-CVLS, corresponding to residues 186-189) with: (i) that of the nonisoprenylated IP control -SSLC sequence, to generate Ha-Ras ${ }^{\text {SSLC }}$; (ii) that of the geranylgeranylated Rac 1 -CVLL sequence, to generate $\mathrm{Ha}-\mathrm{Ras}^{\mathrm{CVLL}}$; or (iii) that of the alternatively isoprenylated Ki-Ras 4B -CVIM sequence, to generate Ha-Ras ${ }^{\text {CVIM. This }}$ experimental approach of replacing the CAAX motif of Ha-Ras with those of other isoprenylated proteins first allows for a direct comparison between the various -CAAX motifs under study as substrates for isoprenylation, either in vitro or in whole cells (in vivo). Secondly, in the case of the IP, this approach is necessitated by the inability to translate the seven-transmembrane receptor in an in vitro system and, thirdly, by the difficulty in expressing the IP at sufficiently high levels in mammalian systems to facilitate its efficient metabolic labelling with $\left[{ }^{3} \mathrm{H}\right] \mathrm{MVA}$ in vivo in intact cells which may, in turn, obscure interpretation of data generated in the presence of SCH66336.

Initially, we employed an in vitro assay approach to directly compare the effect of SCH66336 on the isoprenylation and farnesylation of Ha-Ras and its variants. To this end, cDNA sequences encoding Ha-Ras ${ }^{\mathrm{WT}}$, Ha-Ras ${ }^{\mathrm{CSLC}}$, Ha-Ras ${ }^{\mathrm{SSLC}}$, Ha-Ras ${ }^{\mathrm{CVLL}}$ and $\mathrm{Ha}-\mathrm{Ras}^{\mathrm{CVIM}}$ were transcribed and translated in vitro. Based on the incorporation of $\left[{ }^{35} \mathrm{~S}\right]$ methionine, all proteins were synthesized with comparable efficiencies (Figure 6A, lanes 1-5), whereas the level of endogenous protein synthesis in the absence
(A)

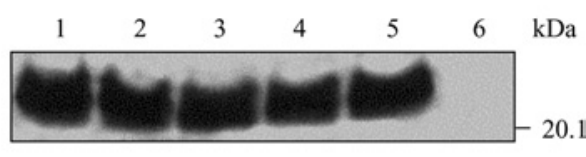

(B)

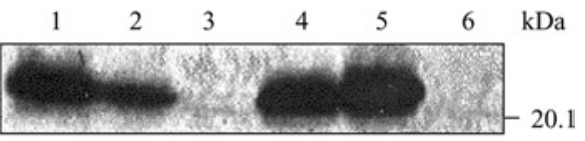

(C)

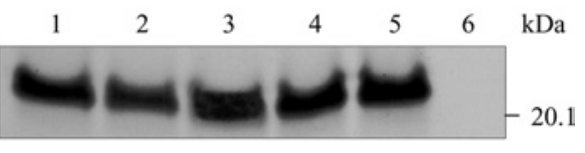

(D)

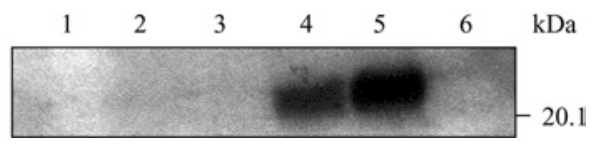

Figure 6 Effect of SCH66336 on isoprenylation of the -CSLC motif in vitro

RNA transcripts coding for Ha-Ras (lane 1), Ha-Ras ${ }^{\text {CSLC (lane 2), Ha-Ras }}{ }^{\text {SSLC (lane 3), Ha-Ras }}$ CVLL (lane 4) and Ha-Ras CVIM (lane 5) were translated in vitro in the presence of [35 S]methionine (A), [ $\left.{ }^{3} \mathrm{H}\right] \mathrm{MVA}$ (B), [ ${ }^{35}$ S]methionine plus MVA (C) or [ $\left.{ }^{3} \mathrm{H}\right] \mathrm{MVA}$ plus $25 \mathrm{nM} \mathrm{SCH66336}$ (D), as described in the Experimental section. Parallel in vitro translations carried out in the absence of exogenous added RNA served as controls for ${ }^{35}$ S] $]$ methionine and $\left[{ }^{3} \mathrm{H}\right] \mathrm{MVA}$ reactions (A-D, lanes 6). Aliquots from each translation reaction $\left(8 \mu \mathrm{l}\right.$ from $\left.{ }^{35} \mathrm{~S}\right]$ methionine reactions and $25 \mu \mathrm{l}$ from [ ${ }^{3} \mathrm{H}$ ]MVA reactions) were resolved by SDS/PAGE and electroblotted on to PVDF membranes. Thereafter, blots were subjected to fluorography to visualize the radiolabelled proteins. Blots containing ${ }^{35} \mathrm{~S}$-labelled proteins ( $\mathbf{A}$ and $\mathbf{C}$ ) were exposed for $16 \mathrm{~h}$, while those containing ${ }^{3} \mathrm{H}$-labelled proteins ( $\mathbf{B}$ and $\mathbf{D}$ ) were exposed for 21 days. The position of a $20.1 \mathrm{kDa}$ molecular-mass marker $(\mathrm{kDa})$ is indicated to the right of $(\mathbf{A})-(\mathbf{D})$.

of exogenous RNA was negligible (Figure 6A, lane 6). Thereafter, to investigate the effect of SCH66336 on the isoprenylation of Ha-Ras ${ }^{\mathrm{WT}}$ and the four chimaeric Ha-Ras mutants, parallel in vitro translation reactions were allowed to proceed either in the presence of the radiolabelled isoprenoid precursor $\left[{ }^{3} \mathrm{H}\right] \mathrm{MVA}$, which can be readily converted into the isoprenoid donors FPP and GGPP by the reticulocyte lysate system [14], or in the presence of the isoprenoid donors $\left[{ }^{3} \mathrm{H}\right] \mathrm{FPP}$ or $\left[{ }^{3} \mathrm{H}\right] \mathrm{GGPP}$. Again, all proteins were synthesized with comparable efficiencies in the presence of MVA on the basis of the incorporation of $\left[{ }^{35} \mathrm{~S}\right]$ methionine (Figure 6C, lanes 1-6). In the presence of $\left[{ }^{3} \mathrm{H}\right] \mathrm{MVA}$ alone, single protein bands of $21 \mathrm{kDa}$ corresponding to isoprenylated $\mathrm{Ha}^{-\mathrm{Ras}^{\mathrm{WT}}}{ }^{\text {, Ha-Ras }}{ }^{\mathrm{CSLC}}$, Ha-Ras ${ }^{\mathrm{CVLL}}$ and Ha-Ras ${ }^{\mathrm{CVIM}}$ were readily detected (Figure 6B, lanes 1, 2, 4 and 5) whereas no $\left[{ }^{3} \mathrm{H}\right] \mathrm{MVA}$ was incorporated into Ha-Ras ${ }^{\text {SSLC }}$ (Figure 6B, lane 3) confirming that mutation of the critical Cys ${ }^{186}$ to Ser $^{186}$ within the CaaX motif of Ha-Ras ${ }^{\mathrm{CSLC}}$ abolished isoprenylation. Moreover, in the absence of exogenous RNA, no detectable $\left[{ }^{3} \mathrm{H}\right]$ MVA was incorporated into endogenous proteins within the reticulocyte lysate system itself (Figure 6B, lane 6). Whereas the inclusion of $25 \mathrm{nM}$ SCH66336 (Figure 6D; or $1 \mu \mathrm{M}$, results not shown) during in vitro translation reactions had no effect on the ability to translate the HaRas proteins, as assessed by the incorporation of $\left[{ }^{35} \mathrm{~S}\right]$ methionine (results not shown), it abolished $\left[{ }^{3} \mathrm{H}\right] \mathrm{MVA}$ incorporation into $\mathrm{Ha}^{-\mathrm{Ras}^{\mathrm{WT}}}$ and Ha-Ras ${ }^{\mathrm{CSLC}}$ (Figure 6D, lanes 1 and 2) while incorporation of $\left[{ }^{3} \mathrm{H}\right] \mathrm{MVA}$ into Ha-Ras ${ }^{\mathrm{CVLL}}$, a known substrate for GGTase 1, was unaffected by SCH66336 (Figure 6D, lane 4). Consistent with the ability of $\mathrm{Ki}$-Ras to undergo alternative geranylgeranylation in the presence of FTIs [19-21], [ $\left.{ }^{3} \mathrm{H}\right] \mathrm{MVA}$ incorporation into Ha-Ras ${ }^{\text {CVIM }}$ was not affected by SCH66336 (Figure 6D, lane 5). Indeed, incorporation of the mevalonate label into Ha-Ras ${ }^{\text {CVIM }}$ was not substantially inhibited by an increased concentration of SCH66336 (1 $\mu \mathrm{M}$; results not shown). 


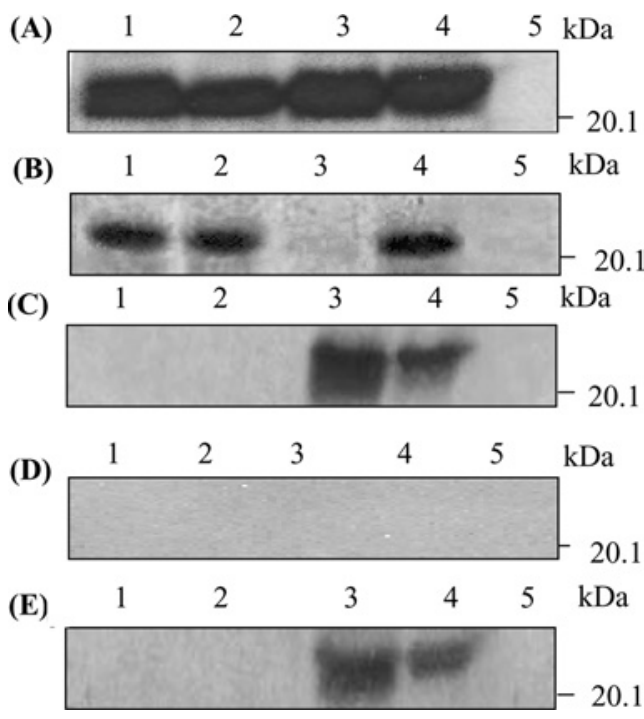

\section{Figure 7 Effect of SCH66336 on incorporation of $\left[{ }^{3} \mathrm{H}\right] \mathrm{FPP}$ and $\left[{ }^{3} \mathrm{H}\right] \mathrm{GGPP}$ into Ras translation products}

RNA transcripts coding for Ha-Ras (lane 1), Ha-Ras CSLC (lane 2), Ha-Ras CVLL (lane 3), Ha-Ras ${ }^{\text {CVIM }}$ (lane 4) were translated in vitro in the presence of $\left[{ }^{35}\right.$ S] methionine $(\mathbf{A}),\left[{ }^{3} \mathrm{H}\right] \mathrm{FPP}(\mathbf{B}),\left[{ }^{3} \mathrm{H}\right] \mathrm{GGPP}$ (C). ${ }^{3}$ HIFPP plus $25 \mathrm{nM} \mathrm{SCH66336} \mathrm{(D)} \mathrm{or} \mathrm{[}{ }^{3}$ H]GGPP plus $25 \mathrm{nM}$ SCH66336 (E) as described in the Experimental section. Parallel in vitro translations carried out in the absence of exogenous added RNA served as controls for $\left[{ }^{35} \mathrm{~S}\right]$ methionine, $\left[{ }^{3} \mathrm{H}\right] \mathrm{FPP}$ and $\left[{ }^{3} \mathrm{H}\right] \mathrm{GGPP}$ reactions respectively (A-E, lanes 5). Aliquots from each translation reaction (8 $\mu$ l from ${ }^{35}$ S] Sethionine reactions and $25 \mu \mathrm{l}$ from $\left[{ }^{3} \mathrm{H}\right] \mathrm{FPP}$ and $\left[{ }^{3} \mathrm{H}\right] \mathrm{GGPP}$ reactions) were resolved by SDS/PAGE and electroblotted on to PVDF membranes. Thereafter, blots were subjected to fluorography to visualize the radiolabelled proteins. Blots containing ${ }^{35}$ S-labelled proteins were exposed for $16 \mathrm{~h}(\mathbf{A})$, whereas those containing ${ }^{3} \mathrm{H}$-labelled proteins were exposed for 21 days $(\mathbf{B}-\mathbf{E})$. The position of a $20.1 \mathrm{kDa}$ molecular-mass marker $(\mathrm{kDa})$ is indicated to the right of $(\mathbf{A})-(\mathbf{E})$.

The specificity of SCH66336 inhibition on the modifications of the Ras proteins by either FPP or GGPP was evaluated further in which Ha-Ras ${ }^{\text {WT }}$, Ha-Ras ${ }^{\mathrm{CSLC}}$, Ha-Ras ${ }^{\mathrm{CVLL}}$ and Ha-Ras ${ }^{\mathrm{CVIM}}$ were translated in the presence of the direct isoprene donors $\left[{ }^{3} \mathrm{H}\right] \mathrm{FPP}$ or $\left[{ }^{3} \mathrm{H}\right]$ GGPP. In agreement with the $\left[{ }^{3} \mathrm{H}\right] \mathrm{MVA}$ data, Ha-Ras ${ }^{\mathrm{WT}}$, Ha-Ras ${ }^{\text {CSLC }}$ and Ha-Ras ${ }^{\text {CVIM }}$ were all efficiently farnesylated (Figure 7A, lanes 1, 2 and 4), whereas the GGTase 1 control substrate Ha-Ras ${ }^{\mathrm{CVLL}}$ failed to incorporate any $\left[{ }^{3} \mathrm{H}\right] \mathrm{FPP}$ label (Figure 7B, lane 3). Inclusion of SCH66336 (25 nM) during the in vitro translation reactions inhibited $\left[{ }^{3} \mathrm{H}\right] \mathrm{FPP}$ incorporation into Ha-Ras ${ }^{\mathrm{WT}}$, Ha-Ras ${ }^{\text {CSLC }}$ and Ha-Ras ${ }^{\text {CVIM }}$ (Figure 7D, lanes 1, 2 and 4). On the other hand, while Ha-Ras ${ }^{\mathrm{WT}}$ and Ha-Ras ${ }^{\mathrm{CSLC}}$ failed to incorporate the $\left[{ }^{3} \mathrm{H}\right]$ GGPP label (Figure 7C, lanes 1 and 2), both Ha-Ras ${ }^{\mathrm{CVL}}$ and $\mathrm{Ha}-\mathrm{Ras}^{\mathrm{CVIM}}$ were efficiently geranylgeranylated in the presence of $\left[{ }^{3} \mathrm{H}\right] \mathrm{GGPP}$ (Figure 7C, lanes 3 and 4). Moreover, inclusion of SCH66336 (25 nM) during the in vitro translation reaction fully supported the alternative geranylgeranylation of $\mathrm{Ha}-$ Ras $^{\mathrm{CVIM}}$ (Figure 7E, lane 4). As expected, SCH66336 had no effect on labelling of the GGTase 1 substrate control Ha-Ras ${ }^{\text {CVLL }}$ (Figure 7E, lane 3).

\section{The effect of SCH66336 on protein isoprenylation in vivo}

Thereafter, to investigate whether SCH66336 impairs isoprenylation of the -CSLC motif of the IP in vivo, whole-cell metabolic labelling studies were carried out in the presence of $\left[{ }^{3} \mathrm{H}\right] \mathrm{MVA}$ in HEK-293 cells transiently transfected with plasmids encoding

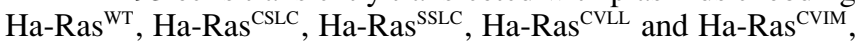
where cells transfected with the empty vector served as a control. Following metabolic labelling, whole-cell protein was either analysed directly, or HA-epitope-tagged Ras proteins were immunoprecipitated and analysed for labelling by fluorography. In
(A)

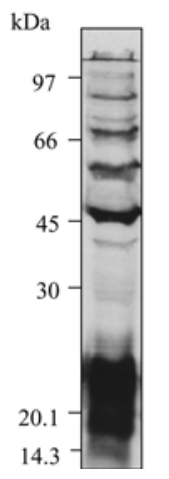

(B)

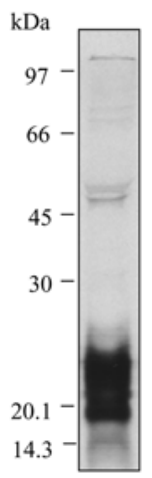

(C)

(D)

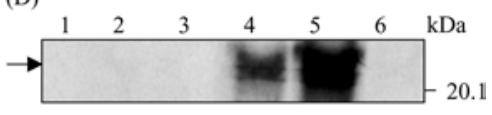

(E)

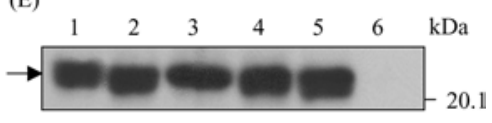

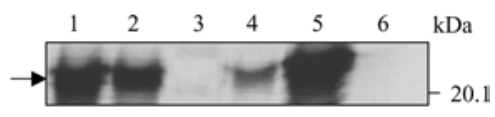

Figure 8 Effect of SCH66336 on the isoprenylation of the -CSLC motif in whole cells

HEK-293 cells were transiently co-transfected with pMEV along with pHM:Ras WT , pHM:Ras CSLC, pHM:Ras ${ }^{\text {SLC }}$, pHM:Ras ${ }^{\text {CVLL }}$, pHM:Ras ${ }^{\text {CVIM }}$ or, as a negative control, the empty vector pHM6 before metabolic labelling with $\left.{ }^{3} \mathrm{H}\right] \mathrm{MVA}$ either in the absence $(\mathbf{A}$ and $\mathbf{C})$ or the presence $(\mathbf{B}$ and D) of SCH66336. (A) and (B) To analyse the effect of SCH66336 on total metabolic labelling, aliquots $(60 \mu \mathrm{g}$ ) of whole-cell proteins isolated from cells labelled in the absence $(\mathbf{A})$ or presence (B) of $1 \mu \mathrm{M} \mathrm{SCH66336} \mathrm{were} \mathrm{resolved} \mathrm{directly} \mathrm{by} \mathrm{SDS/PAGE,} \mathrm{followed} \mathrm{by} \mathrm{electroblotting} \mathrm{on} \mathrm{to}$ PVDF membranes, where proteins isolated from the mock (pHM6)-transfected HEK-293 cells are shown as representatives in (A) and (B). (C) and (D) Alternatively, cell lysates from the respective transfected cells (containing approx. $500 \mu \mathrm{g}$ of protein/lysate) were subjected to immunoprecipitation with anti-HA 101r serum to immunoprecipitate the HA-tagged Ha-RasWT (lane 1), Ha-Ras CSLC (lane 2), Ha-Ras SSLC (lane 3), Ha-Ras ${ }^{\text {CVLL (lane 4) and Ha-Ras }}{ }^{\text {CVIM }}$ (lane 5), where cell lysates from mock-transfected HEK-293 cells (pHM6, lane 6) served as negative controls. Immunoprecipitates were resolved by SDS/PAGE, followed by electroblotting on to a PVDF membrane. Blots in (A)-(D) were then soaked in Amplify for 30 min and exposed to X-Omat AR 5 film for 21 days at $-70^{\circ} \mathrm{C}$. (E) In parallel experiments, HA-tagged proteins immunoprecipitated from non-metabolically labelled HEK-293 cells transiently co-transfected with pMEV, along with either pHM:Ras ${ }^{\text {WT }}$ (lane 1), pHM:Ras ${ }^{\text {CSLC }}$ (lane 2), pHM:Ras ${ }^{\text {SLC }}$ (lane 3), pHM:Ras CVLL(lane 4), pHM:Ras CVIM (lane 5) or, as a negative control, pHM6 (lane 6) were resolved by SDS/PAGE, followed by electroblotting on to a PVDF membrane; thereafter, membranes were screened using the peroxidase-conjugated anti-HA $3 \mathrm{~F} 10$ serum followed by chemiluminescent detection. The positions of the molecular-mass markers $(\mathrm{KDa})$ are indicated either to the left or right of $(\mathbf{A})-(\mathbf{E})$, and the position of the isoprenylated $21.4 \mathrm{kDa}$ protein corresponding to $\mathrm{Ha} a$-Ras, Ha-Ras ${ }^{\mathrm{SLC}}$, Ha-Ras ${ }^{\text {SLC }}$, Ha-Ras ${ }^{\mathrm{CVL}}$ or Ha-Ras ${ }^{\text {CVIM }}$ are indicated by an arrow (C-E).

parallel experiments, the quantitative immunoprecipitation and the identities of the precipitated/isoprenylated proteins to be those of the HA-tagged Ras ${ }^{\mathrm{WT}}$, $\operatorname{Ras}^{\mathrm{CSLC}}$, Ras ${ }^{\mathrm{SSLC}}$, Ras $^{\mathrm{CVLL}}$ and Ras ${ }^{\mathrm{CVIM}}$ were each confirmed by direct screening of Western blots with peroxidase-conjugated anti-HA 3F10 antibody (Figure 8E). In the absence of SCH66336, there was efficient uniform isoprenylation as evidenced by the incorporation of $\left[{ }^{3} \mathrm{H}\right] \mathrm{MVA}$-derived isoprene units into a host of cell proteins, irregardless of transfection type (Figure 8A). Moreover, following immunoprecipitation with the anti-HA antibody, it was evident that Ha-Ras ${ }^{\text {WT }}$, Ha-Ras ${ }^{\mathrm{CSLC}}$, Ha$\mathrm{Ras}^{\mathrm{CVLL}}$ and Ha-Ras ${ }^{\mathrm{CVIM}}$ were efficiently isoprenylated (Figure 8C, lanes 1, 2, 4 and 5), whereas no $\left[{ }^{3} \mathrm{H}\right] \mathrm{MVA}$ was incorporated into Ha-Ras ${ }^{\text {SSLC }}$ and no $\left[{ }^{3} \mathrm{H}\right]$ MVA was immunoprecipitated in the control/mock-transfected HEK-293 cells (Figure 8C, lanes 3 and 6). Inclusion of SCH66336 ( $1 \mu \mathrm{M}$; or $25 \mathrm{nM}$, results not shown) during the labelling reaction significantly reduced the incorporation of $\left[{ }^{3} \mathrm{H}\right] \mathrm{MVA}$ into the range of endogenous cellular isoprenylated proteins, particularly those greater than $45 \mathrm{kDa}$ (Figure 8B) and, more specifically, completely obliterated isoprenylation of Ha-Ras ${ }^{\mathrm{WT}}$ and Ha-Ras ${ }^{\mathrm{CSLC}}$ (Figure 8D, lanes 1 and 2). Consistent with the in vitro data, SCH66336 did not affect isoprenylation of the GGTase 1 substrate Ha-Ras ${ }^{\mathrm{CVLL}}$ (Figure 8D, lane 4) or Ha-Ras ${ }^{\mathrm{CVIM}}$ (Figure 8D, lane 5), confirming that HaRas $^{\mathrm{CVIM}}$ becomes alternatively processed in the presence of strong FTase inhibition. 


\section{DISCUSSION}

FTIs were originally developed to block constitutive signalling by mutant Ras proteins [22]. However, current evidence suggests that FTIs have broad anticancer action, an activity that in some instances is not necessarily correlated with the presence of mutated ras oncogenes [22-24]. Identification of the critical targets or other potential effects of FTI action is the key outstanding question in gaining full knowledge as to the true efficacy of these drugs in vivo. SCH66336 is an orally active tricyclic compound that has entered phase II/III clinical trials for the treatment of various cancers, including pancreatic cancer, glioblastoma and solid tumours [5,6]. In addition to its FTase inhibition of Ras, data herein demonstrate that SCH66336 exhibits substantial inhibition of IP function through impairment of IP farnesylation and intracellular signalling.

Along with nitric oxide (NO), prostacyclin acts synergistically on smooth-muscle cells, leucocytes and platelets, playing a major role in maintaining vascular integrity and blood fluidity [7]. Moreover, prostacyclin is a potent pro-inflammatory mediator and has also been proposed as an anticancer prostanoid, given its antiproliferative, anti-apoptotic and anti-metastatic nature/properties seen in experimental tumour models [25-28]. Although the role of prostacyclin in angiogenesis has not been fully examined, there is evidence for both pro- and anti-angiogenic effects [29-33]. The IP is primarily coupled to $\mathrm{G}_{\mathrm{s}}$-dependent activation of adenylate cyclase, but can also couple to $\mathrm{G}_{\mathrm{q}} / \mathrm{PLC} \beta$ [34]. The IP appears to be unique among the GPCRs in that it undergoes farnesylation and palmitoylation, post-translational modifications that are critical for IP function $[11,12,15,35]$.

Given the ambiguity surrounding the mechanism of action of the FTIs and their true targets [5,23,24], the current study examined the effect of SCH66336 on signalling by both the hIP and mIP stably expressed in HEK-293 cells, and by the hIP endogenously expressed in HEL cells. Pre-treatment of HEK.hIP, HEK.mIP and HEL cells with SCH66336 $(1 \mu \mathrm{M})$ for $16 \mathrm{~h}$ reduced hIP- and mIP-mediated cAMP generation to approx. $28.6 \pm$ $7.1 \%, 25.7 \pm 9.4 \%$ and $19.1 \pm 1.2 \%$ respectively, whereas $1 \mu \mathrm{M}$ SCH66336 reduced hIP-, mIP- and HEL-mediated $\left[\mathrm{Ca}^{2+}\right]_{\mathrm{i}}$ mobilization to $37.1 \pm 3 \%, 38.0 \pm 5.5 \%$ and $26.8 \pm 7.1 \%$ respectively. Moreover, these reductions in IP-mediated cAMP generation and $\left[\mathrm{Ca}^{2+}\right]_{\mathrm{i}}$ mobilization occurred in a concentrationdependent manner. Conversely, SCH66336 had no effect on $\left[{ }^{3} \mathrm{H}\right]-$ iloprost binding, excluding the possibility that the reduction in IP function was attributable to an overall decrease in IP expression. No significant decreases in $\beta_{2} \mathrm{AR}$-mediated cAMP generation or TP $\beta$-mediated $\left[\mathrm{Ca}^{2+}\right]_{\mathrm{i}}$ mobilization occurred, confirming that the reductions elicited by SCH66336 are targeted to the IP itself and not to another component of the signalling system. Whereas SCH66336 $(1 \mu \mathrm{M})$ also significantly reduced the extent and kinetics of cicaprost-induced IP internalization, from concentration-response studies it was shown that SCH66336 at concentrations lower than $0.1 \mu \mathrm{M}$ did not yield significant reductions in IP internalization (results not shown). Hence, comparing our data herein, it is evident that IP-mediated intracellular signalling (cAMP generation and $\left[\mathrm{Ca}^{2+}\right]_{\mathrm{i}}$ mobilization) are substantially more sensitive to inhibition by SCH66336 than is agonist-mediated IP internalization. It is, however, indeed noteworthy that the circulating plasma concentrations in humans taking $200 \mathrm{mg}$ of SCH66336 twice daily achieve levels greater than $1 \mu \mathrm{M}$ [36], and therefore represent levels substantially higher than those required to inhibit IP signalling and agonist-induced IP internalization in whole cells.

Cross-desensitization or counter-regulation of responses is widely documented to occur between the anti-aggregatory adenyl- ate cyclase/PKA system elicited by prostacyclin and the proaggregatory PLC $\beta / \mathrm{PKC}$ system elicited by $\mathrm{TXA}_{2}$ in platelets and vascular smooth muscle $[8,13,37]$. More specifically, the $\mathrm{TP} \alpha$, but not the $\mathrm{TP} \beta$, isoform of the human $\mathrm{TXA}_{2}$ receptor undergoes IP-mediated desensitization through direct PKA phosphorylation of TP $\alpha$ within its C-tail domain [13]. Given the central role of the latter counter-regulation between IP and TP $\alpha$ signalling, coupled with the finding that SCH66336 is a potent inhibitor of IP function, we next examined the effect of SCH66336 on IP-mediated desensitization or counter-regulation of the TP responses. Consistent with previous studies, both $\mathrm{TP} \alpha$ and $\mathrm{TP} \beta$ exhibited efficient $\mathrm{U} 46619$-induced $\left[\mathrm{Ca}^{2+}\right]_{\mathrm{i}}$ mobilization $[13,15]$, a response not significantly altered by SCH66336. Pre-stimulation of the endogenous IP with cicaprost significantly desensitized subsequent U46619-mediated $\left[\mathrm{Ca}^{2+}\right]_{\mathrm{i}}$ mobilization by $\mathrm{TP} \alpha$, but not by $\mathrm{TP} \beta$. However, SCH66336 significantly reduced the level of cicaprostmediated desensitization of TP $\alpha$ signalling in a concentrationdependent manner ( $\mathrm{IC}_{50} 56.1 \mathrm{nM} \mathrm{SCH66336).} \mathrm{On} \mathrm{the} \mathrm{other} \mathrm{hand,}$ U46619-induced signalling by $\operatorname{TP} \beta$ was unaffected by cicaprost, irrespective of the presence/absence of SCH66336.

The ubiquitously expressed HDJ-2 is farnesylated and undergoes a mobility shift upon treatment with FTI [18]. Thus the detection and relative abundance of the farnesylated and nonfarnesylated forms of HDJ-2 through immunoblot analysis offers a convenient method to assess SCH66336 potency and, herein, allowed us to compare the relative inhibitory effects of SCH66336 on the isoprenylation of the IP to that of HDJ-2. Given that the $\mathrm{IC}_{50}$ for inhibition of cicaprost-induced cAMP generation reported herein ranged from 0.27 to $0.62 \mathrm{nM} \mathrm{SCH66336,} \mathrm{and}$ the $\mathrm{IC}_{50}$ for inhibition of HDJ-2 isoprenylation was $3.07 \mathrm{nM}$, it is indeed apparent that IP isoprenylation and primary signalling (agonist-induced cAMP generation) is 5-10-fold more sensitive to SCH66336 inhibition than is HDJ-2.

FTIs offer an appealing paradigm for the rational design and development of novel anticancer agents, such as SCH66336, as they exploit the necessary farnesylation of Ras, and so inhibit its oncogenic potential [5]. However, while all four Ras proteins are efficient substrates for FTase [4], numerous studies have demonstrated that, in the presence of FTIs, N-Ras, Ki-Ras 4A and Ki-Ras 4B may become alternatively geranylgeranylated [19-21,24]. Nonetheless, FTI treatment can significantly inhibit the growth of tumours containing Ki-Ras mutations [38-40], suggesting either that other farnesylated cellular protein(s) distinct from Ras may also play a role in the biological consequences of FTI treatment [41], or that farnesylated and geranylgeranylated Ki-Ras may function differently [24]. Other farnesylated proteins that have been suggested to be possible FTI targets include RhoB, the centromere-binding proteins CENP-E and CENP-F, and the nuclear lamins [23]. However, to date, no protein has been identified that can directly account for all the actions of FTI, and hence studies aimed at investigating their effects on other farnesylated proteins, such as the IP, are critical for the identification of the major targets of FTI and, secondly, for our detailed understanding of the complete mode of action of FTIs.

In the present study, we sought to establish whether SCH66336 could inhibit IP isoprenylation both in vitro and in vivo and/or whether, analogous to that of Ki-Ras and N-Ras, the IP could become alternatively isoprenylated in the presence of SCH66336. To this end, we generated a series of chimaeric Ha-Ras variants. The experimental approach adopted not only allowed for a direct comparison between the various -CAAX motifs under study, but it was also largely necessitated both by an inability to translate the full-length IP in vitro and the relatively inefficient metabolic labelling of the IP with the isoprene precursor $\left[{ }^{3} \mathrm{H}\right] \mathrm{MVA}$ in vivo, thereby potentially obscuring interpretation of data in the presence 
of the FTI. In the absence of SCH66336, Ha-Ras ${ }^{\text {WT }}$, Ha-Ras ${ }^{\text {CSLC }}$ and Ha-Ras ${ }^{\text {CVIM }}$ chimaeras were all preferentially modified by 15 carbon farnesyl isoprenoids both in vitro and in vivo. Consistent with previous studies [14], changing the terminal serine residue of Ha-Ras to leucine rendered Ha-Ras ${ }^{\mathrm{CVLL}}$ a substrate for geranylgeranyl modification in vitro and in vivo, while mutation of the critical acceptor cysteine of Ha-Ras ${ }^{\mathrm{CSLC}}$ to Ha-Ras ${ }^{\mathrm{SSLC}}$ completely abolished isoprenylation. In the presence of SCH66336, HaRas $^{\mathrm{WT}}$ and Ha-Ras ${ }^{\mathrm{CSLC}}$ isoprenylation was completely inhibited, suggesting that, unlike Ki-Ras and N-Ras, the C-terminal regions of both Ha-Ras (-CVLS) and IP (-CSLC) do not undergo alternative geranylgeranylation either in vitro or in vivo. As expected, inclusion of SCH66336 had no effect on isoprenylation of the control Ha-Ras ${ }^{\text {SSLC }}$ or on the geranylgeranylated Rac 1, Ha-Ras ${ }^{\mathrm{CVLL}}$ sequence either in vitro or in vivo. However, SCH66336 resulted in a marked increase in isoprenylation of Ha-Ras ${ }^{\mathrm{CVIM}}$, confirming that, although SCH66336 inhibits farnesylation of the variant Ha$\mathrm{Ras}^{\mathrm{CVIM}}$, it can become alternatively geranylgeranylated in the presence of FTI, and thus serves as a GGTase 1 substrate in vitro and in vivo.

Hence, taken together, these data confirm that the -CSLC motif corresponding to the -CaaX motif of the IP supports the efficient isoprenylation of Ha-Ras and that, unlike the -CVIM motif (naturally found associated with $\mathrm{Ki}-\mathrm{Ras} 4 \mathrm{~B}$ ), farnesylation of the -CSLC motif is completely inhibited by SCH66336, and does not undergo alternative geranylgeranylation in the presence of this FTI. Hence, in view of the recognized functional requirement for isoprenylation by the IPs from a range of species $[11,12,15]$, coupled with the observed effects of SCH66336 on IP signalling and function reported herein, it is likely that the IP is a direct target of SCH66336 inhibition which may, in turn, contribute to the more diverse actions of FTIs other than Ras targeting. Whether the therapeutic use of SCH66336 can impair IP-mediated cellular processes in vivo or in human subjects is of course currently unknown. However, it is indeed noteworthy that the $\mathrm{IC}_{50}$ values for cAMP generation $\left(\mathrm{IC}_{50} 0.27-0.62 \mathrm{nM}\right)$ and $\left[\mathrm{Ca}^{2+}\right]_{\mathrm{i}}$ mobilization $\left(\mathrm{IC}_{50} 26.6-48.3 \mathrm{nM}\right)$ are significantly lower than typical plasma concentrations that are reported to be greater than $1 \mu \mathrm{M}$ in patients receiving $200 \mathrm{mg}$ of SCH66336 twice daily [36]. In view of this and the data presented herein, the effect of SCH66336 on IPsignalling and function in human subjects remains to be critically addressed at the detailed molecular level.

This work was supported by The Wellcome Trust, The Health Research Board, Enterprise Ireland and The Irish Heart Foundation. We thank Schering Plough Research Institute, Kenilworth, U.S.A. and Schering AG, Germany for the gifts of SCH66336 and cicaprost respectively.

\section{REFERENCES}

1 Adjei, A. A. (2001) Blocking oncogenic Ras signaling for cancer therapy. J. Natl. Cancer. Inst. 93, 1062-1074

2 Downward, J. (2003) Targeting RAS signalling pathways in cancer therapy. Nat. Rev. Cancer 3, 11-22

3 McCormick, F. (1999) Signalling networks that cause cancer. Trends Cell. Biol. 9, M53-M56

4 Zhang, F. L. and Casey, P. J. (1996) Protein prenylation: molecular mechanisms and functional consequences. Annu. Rev. Biochem. 65, 241-269

5 Caponigro, F. (2002) Farnesyl transferase inhibitors: a major breakthrough in anticancer therapy? Naples, 12 April 2002. Anticancer Drugs. 13, 891-897

6 Haluska, P., Dy, G. K. and Adjei, A. A. (2002) Farnesyl transferase inhibitors as anticancer agents. Eur. J. Cancer. 38, 1685-1700

7 Narumiya, S., Sugimoto, Y. and Ushikubi, F. (1999) Prostanoid receptors: structures, properties and functions. Physiol. Rev. 79, 1193-1226

8 Cheng, Y., Austin, S. C., Rocca, B., Koller, B. H., Coffman, T. M., Grosser, T., Lawson, J. A. and FitzGerald, G. A. (2002) Role of prostacyclin in the cardiovascular response to thromboxane A2. Science 296, 539-541
9 Fitzgerald, D. J., Entman, S. S., Mulloy, K. and FitzGerald, G. A. (1987) Decreased prostacyclin biosynthesis preceding the clinical manifestation of pregnancy-induced hypertension. Circulation 75, 956-963

10 Kahn, N. N., Mueller, H. S. and Sinha, A. K. (1990) Impaired prostaglandin E1//2 receptor activity of human blood platelets in acute ischemic heart disease. Circ. Res. 66, 932-940

11 Hayes, J. S., Lawler, O. A., Walsh, M. T. and Kinsella, B. T. (1999) The prostacyclin receptor is isoprenylated. Isoprenylation is required for efficient receptor-effector coupling. J. Biol. Chem. 274, 23707-23718

12 Miggin, S. M., Lawler, O. A. and Kinsella, B. T. (2002) Investigation of a functional requirement for isoprenylation by the human prostacyclin receptor. Eur. J. Biochem. 269 , $1714-1725$

13 Walsh, M. T., Foley, J. F. and Kinsella, B. T. (2000) The alpha, but not the beta, isoform of the human thromboxane $A 2$ receptor is a target for prostacyclin-mediated desensitization. J. Biol. Chem. 275, 20412-20423

14 Kinsella, B. T., Erdman, R. A. and Maltese, W. A. (1991) Posttranslational modification of Ha-ras p21 by farnesyl versus geranylgeranyl isoprenoids is determined by the COOH-terminal amino acid. Proc. Natl. Acad. Sci. U.S.A. 88, 8934-8938

15 Lawler, 0. A., Miggin, S. M. and Kinsella, B. T. (2001) The effects of the statins lovastatin and cerivastatin on signalling by the prostanoid IP-receptor. Br. J. Pharmacol. 132 , 1639-1649

16 Adjei, A. A., Davis, J. N., Erlichman, C., Svingen, P. A. and Kaufmann, S. H. (2000) Comparison of potential markers of farnesyltransferase inhibition. Clin. Cancer. Res. 6 , 2318-2325

17 Smyth, E. M., Austin, S. C., Reilly, M. P. and FitzGerald, G. A. (2000) Internalization and sequestration of the human prostacyclin receptor. J. Biol. Chem. 275, 32037-32045

18 Kanazawa, M., Terada, K., Kato, S. and Mori, M. (1997) HSDJ, a human homolog of DnaJ, is farnesylated and is involved in protein import into mitochondria. J. Biochem. (Tokyo) 121, 890-895

19 Zhang, F. L., Kirschmeier, P., Carr, D., James, L., Bond, R. W., Wang, L., Patton, R., Windsor, W. T., Syto, R., Zhang, R. and Bishop, W. R. (1997) Characterization of Ha-ras, $\mathrm{N}$-ras, Ki-Ras4A, and Ki-Ras4B as in vitro substrates for farnesyl protein transferase and geranylgeranyl protein transferase type I. J. Biol. Chem. 272, 10232-10239

20 Whyte, D. B., Kirschmeier, P., Hockenberry, T. N., Nunez-Oliva, I., James, L., Catino, J. J., Bishop, W. R. and Pai, J. K. (1997) K- and N-Ras are geranylgeranylated in cells treated with farnesyl protein transferase inhibitors. J. Biol. Chem. 272, 14459-14464

21 James, G. L., Goldstein, J. L. and Brown, M. S. (1995) Polylysine and CVIM sequences of $\mathrm{K}$-RasB dictate specificity of prenylation and confer resistance to benzodiazepine peptidomimetic in vitro. J. Biol. Chem. 270, 6221-6226

22 Gibbs, J. B. and Oliff, A. (1997) The potential of farnesyltransferase inhibitors as cancer chemotherapeutics. Annu. Rev. Pharmacol. Toxicol. 37, 143-166

23 Bishop, W. R., Kirschmeier, P. and Baum, C. (2003) Farnesyl transferase inhibitors: mechanism of action, translational studies and clinical evaluation. Cancer Biol. Ther. 2 , S96-S104

24 Fiordalisi, J. J., Johnson, II, R. L., Weinbaum, C. A., Sakabe, K., Chen, Z., Casey, P. J. and Cox, A. D. (2003) High affinity for farnesyltransferase and alternative prenylation contribute individually to K-Ras4B resistance to farnesyltransferase inhibitors. J. Biol. Chem. 278, 41718-41727

25 Honn, K. V., Cicone, B. and Skoff, A. (1981) Prostacyclin: a potent antimetastatic agent. Science 212, 1270-1272

26 Keith, R. L., Miller, Y. E., Hoshikawa, Y., Moore, M. D., Gesell, T. L., Gao, B., Malkinson, A. M., Golpon, H. A., Nemenoff, R. A. and Geraci, M. W. (2002) Manipulation of pulmonary prostacyclin synthase expression prevents murine lung cancer. Cancer Res. 62, 734-740

27 Rigas, B., Goldman, I. S. and Levine, L. (1993) Altered eicosanoid levels in human colon cancer. J. Lab. Clin. Med. 122, 518-523

28 Schirner, M., Lichtner, R. B., Graf, H. and Schneider, M. R. (1997) Efficacy of cicaprost on metastasis in advanced tumor disease. Adv. Exp. Med. Biol. 400B, 751-756

29 Hiraoka, K., Koike, H., Yamamoto, S., Tomita, N., Yokoyama, C., Tanabe, T., Aikou, T., Ogihara, T., Kaneda, Y. and Morishita, R. (2003) Enhanced therapeutic angiogenesis by cotransfection of prostacyclin synthase gene or optimization of intramuscular injection of naked plasmid DNA. Circulation 108, 2689-2696

30 Jones, M. K., Wang, H., Peskar, B. M., Levin, E., Itani, R. M., Sarfeh, I. J. and Tarnawski, A. S. (1999) Inhibition of angiogenesis by nonsteroidal anti-inflammatory drugs: insight into mechanisms and implications for cancer growth and ulcer healing. Nat. Med. 5, 1418-1423

31 Murphy, J. F. and Fitzgerald, D. J. (2001) Vascular endothelial growth factor induces cyclooxygenase-dependent proliferation of endothelial cells via the VEGF-2 receptor. FASEB J. 15, 1667-1669

32 Murphy, J. F., Steele, C., Belton, 0. and Fitzgerald, D. J. (2003) Induction of cyclooxygenase- 1 and -2 modulates angiogenic responses to engagement of alphavbeta3. Br. J. Haematol. 121, 157-164 
33 Wharton, J., Davie, N., Upton, P. D., Yacoub, M. H., Polak, J. M. and Morrell, N. W. (2000) Prostacyclin analogues differentially inhibit growth of distal and proximal human pulmonary artery smooth muscle cells. Circulation 102, 3130-3136

34 Wise, H. and Jones, R. L. (1996) Focus on prostacyclin and its novel mimetics. Trends Pharmacol. Sci. 17, 17-21

35 Miggin, S. M., Lawler, O. A. and Kinsella, B. T. (2003) Palmitoylation of the human prostacyclin receptor. Functional implications of palmitoylation and isoprenylation. J. Biol. Chem. 278, 6947-6958

36 Eskens, F. A., Awada, A., Cutler, D. L., de Jonge, M. J., Luyten, G. P., Faber, M. N., Statkevich, P., Sparreboom, A., Verweii, J., Hanauske, A. R. and Piccart, M. (2001) PHase I and pharmacokinetic study of the oral farnesyl transferase inhibitor SCH 66336 given twice daily to patients with advanced solid tumors. J. Clin. Oncol. 19, 1167-1175
37 Coleman, R. W., Marder, V. J., Salzman, E. W. and Hirsh, J. (1994) Hemostasis and Thrombosis: Basic Principles and Clinical Practice, Philadelphia, Lippincott

38 Sun, J., Qian, Y., Hamilton, A. D. and Sebti, S. M. (1995) Ras CAAX peptidomimetic FTI 276 selectively blocks tumor growth in nude mice of a human lung carcinoma with K-Ras mutation and p53 deletion. Cancer Res. 55, 4243-4247

39 Suzuki, N., Urano, J. and Tamanoi, F. (1998) Farnesyltransferase inhibitors induce cytochrome c release and caspase 3 activation preferentially in transformed cells. Proc. Natl. Acad. Sci. U.S.A. 95, 15356-15361

40 Suzuki, N., Del Villar, K. and Tamanoi, F. (1998) Farnesyltransferase inhibitors induce dramatic morphological changes of KNRK cells that are blocked by microtubule interfering agents. Proc. Natl. Acad. Sci. U.S.A. 95, 10499-10504

41 Tamanoi, F., Kato-Stankiewicz, J., Jiang, C., Machado, I. and Thapar, N. (2001) Farnesylated proteins and cell cycle progression. J. Cell. Biochem. Suppl. 37, 64-70

Received 30 July 2004/5 0ctober 2004; accepted 6 October 2004

Published as BJ Immediate Publication 6 October 2004, DOI 10.1042/BJ20041290 